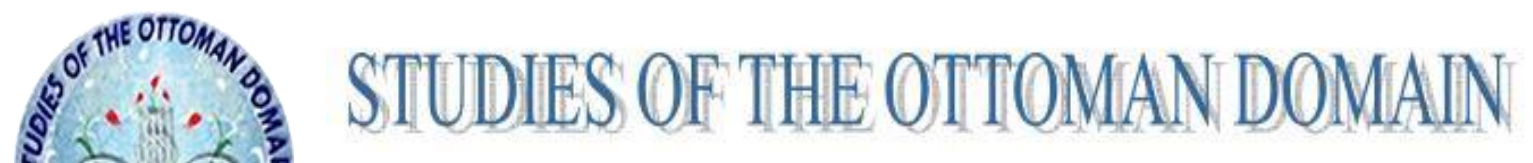

Cilt: 6 Sayı: 11 Ağustos 2016

Issn: 2147-5210

(Doi No : 10.19039/sotod.20161122519)

www.thestudiesofotomandomain.com

\title{
III. AHMED DEVRINDE SUR İÇİ İSTANBUL: YERLEŞİM ALANLARI VE DİĞER ALANLARIN DAĞILIMI*
}

\section{INTERIOR RAMPART CITY OF ISTANBUL IN THE PERIOD OF AHMED III: RESIDENTIAL AREAS AND DISTRIBUTION OF OTHER AREAS}

Tuğba KARA**

\begin{abstract}
Özet
Eski devirlerden beri medeniyetlere başkentlik etmiş olan İstanbul, Fatih'in kenti fethiyle birlikte yeni bir hüviyet kazanmıştır. Fatih fetihten kısa süre sonra hemen kenti imar faaliyetlerine girişmiştir. Fatih'le başlatılan ve Kanunî ile doruk noktasına ulaştırılan imar ve iskân faaliyetleri sonunda, İstanbul Müslümanlar çoğunluk olmak üzere Hristiyan, Yahudi, Ermeni, Çingene gibi dinsel farklılığa göre biçimlendirilmiş bir yapıya dönüşmüştür. Nüfus politikaları ve kentin cazibe merkezi olmaya başlamasıyla birlikte 18. yüzyıla gelindiğinde kent nüfusu oldukça artmıştır. Ancak kentin yapılanmasında daha önceki geleneksel yapının III. Ahmed dönemine gelindiğinde de devam ettiği görülmektedir. Çalışmamızda III. Ahmed dönemi İstanbul Şer‘iyye Sicillerinden hareketle, İstanbul'un yerleşim alanlarının dağılımı, sur içi kentte mahallelerin sayısı ve dini yapıya göre sıralanışı tespit edilmiştir. Bu noktada İstanbul Şer'iyye sicilleri çalışmamızın şekillenmesinde büyük ölçüde belirleyici olmuştur. 1708-1730 arası sicillerde geçen hükümlerden hareketle tek tek mahalle isimleri tespit edilerek, yine davalardan hareketle kentin Müslüman ve gayrimüslim nüfus yapısı belirlenmeye çalıșılmıştır. Yerleşim alanlarının tespiti yapıldıktan sonra kent içindeki yeşil alanların, bağ ve bahçelerin nasıl konumlandı ̆̆ı incelenmiştir. Sonraki aşama da devre ait seyahatname gözlemlerinden hareketle kent siluetinde önemli yere sahip olan çarşı ve pazarlara yer verilmiştir.
\end{abstract}

Anahtar Kelimeler: İstanbul, III. Ahmed, Şer‘iyye Sicilleri, Osmanlı Toplumu, Kent Tarihi

\begin{abstract}
Istanbul, which has been the capital to civilizations since ancient times, has gained a new identity with the conquest of the city by Fatih. Shortly after the conquest of the city, Fatih has immediately embarked on the city development activities. At the end of the development and housing activities that started with Fatih and reached its climax with Kanuni, Istanbul has been transformed into a structure formed by religious differences, the majority of of whom are Muslims as well as Christians, Jews, Armenians and Gypsies. With the beginning of the city to become the attraction center of the urban population and the population policies during the 18th century, the city's population has increased considerably. However, it is observed that earlier traditional structure also continued in the period of Ahmed III in the construction of the city. In our study, starting from III. Ahmed Mughal period Istanbul Court Judge Records of,
\end{abstract}

* Bu makale Tuğba Kara tarafından Samsun 2014 tarihinde Ondokuz Mayıs Üniversitesi Sosyal Bilimler Enstitüsünde III. Ahmed Devrinde Istanbul'da Sosyal ve Kültürel Hayat adı ile tamamlanan Doktora tezindeki İdari ve Sosyal Yapı adlı birinci bölüm içinde yer alan 33 ila 56. sayfalar arasındaki kısmın yeniden gözden geçirilmiş geniş bir özetidir.

${ }^{* *}$ Sinop Üniversitesi, Fen Edebiyat Fakültesi, Tarih Bölümü Öğretim Üyesi, e- mail:tugbakara81@hotmail.com 
distribution of residential area of Istanbul, the number of districts in the interior walls and its order according to religious buildings in the city. At this point Istanbul Sharia records have been a significant determinant in shaping our research. Starting from the cases, it was attempted to determine the Muslim and non-Muslim population of the city structure again by identifying the names of districts one by one with respect to the verdicts that were found in the records between 1708-1730. After the determination of the residential areas of green areas in the city, it has been examined how vineyards and orchards were located. In the next stage, starting from the observations of travelogue belonging to the period, downtowns, markets and bazaars, which were of great importance in the circuit of the city skyline, have been mentioned.

Key Words: Istanbul, Ahmed III, Court Records, Ottoman Society, Urban History

\section{Giriş}

Fatih'le başlatılan ${ }^{1}$ ve Kanuni ile doruk noktasına ulaştırılan imar ve iskân faaliyetleri sonunda, İstanbul'un Müslümanlar çoğunluk olmak üzere Hıristiyan, Yahudi, Ermeni, Çingene vs. gibi dinsel farklılığa göre biçimlendirilmiş kozmopolit bir yapıya büründüğünü söylemek mümkündür. ${ }^{2}$ Müslüman mahalleleri camilerin etrafında şekillenmiştir. Dolayısıyla merkez cami ve mescitler veya bazı diğer yapılar başta hamam, çeşme, medrese olmak kaydıyla Müslüman mahallelerinin burada toplanmasını sağlamıştır. İstanbul'da toplumsal sistem değişik öğelerden kuruluydu. Toplumun birinci bileşenini Müslüman Türkler, ikincisini toplumsal hiyerarşide ikincil konumda görünseler de ekonomik yaşamda önemli yeri olan gayrimüslimler, üçüncü bileşeni saray ve etrafının temsil ettiği devlet oluşturuyordu.

XVIII. yüzyıl İstanbul'unda mahalle içinde ekonomik, dinî ve sosyal hayatında belirgin bir statü farklılaşması yoktur. Değişik zümre ve meslekten zengin fakir her seviyeden Müslim ve gayrimüslim ailelerin farklı büyüklükteki evlerde yan yana yaşadığı görülmektedir. Yalnız fethin ardından kurulan bazı mahallerde ilk devirlerde olduğu gibi bu yüzyılda da ulema, vüzera, müderris gibi kişiler yanında önemli devlet görevlileri (vezir, defterdar, kazasker gibi kimselerin) ikamet ettikleri görülmektedir.

1 E. Hakkı Ayverdi, Fatih Devri Sonlarında İstanbul Mahalleleri, Şehrin İskânı ve Nüfusu, Ankara: Vakıflar Umum Müdürlüğü Yay., 1958, ss.70-72, 80.

2 Evliya Çelebi bu konuyla ilgili olarak bazı bilgiler vermiştir. "Anadolu'dan ve Rumeli'den vilayet vilayet adam getirilerek İstanbul imar edilmiştir. Rumeli’den Üsküb halkı Üsküblü mahallesine, Yenişehir halkı Yeni Mahalleye, Sofya halkı Ayasofya'ya, Mora Rumları Fener kapısına yerleştirilmiştir. Selanik Yahudilerinin 50 cemaati ise Tekfur Sarayı ile Şuhud kapısına getirildi. Bunun için buraya Çıfıt kapısı da denilmiştir. Anadolu civarından Aksaraylılar Aksaray mahallesine, Akka-Gazze ve Ramle'den gelen Araplar Tahtakale'ye oturtuldu. Acem (İran)den gelenler Mahmutpaşa'daki Hoca Hanına, Balat şehrinden gelen Çingeneler Balat Mahallesine getirildi. Arnavutlar Silivri kapı'ya, Safet Yahudileri Hasköy’e, Tokat ve Sivas'tan getirilen Ermeniler Sulu Manastır'a yerleştirilmiştir. Manisalılar Macuncuya, Konyalılar Küçük Karaman'a, Çarşamba ovasından getirilenler de Çarşamba'ya yerleşti. Samsun ve Sinoplular da Tophane'ye yerleştirildi. Onun için Evliya Çelebi iskân sonucunda. ...Anın içün İslâmı bol ismiyle müsemma ile'l-an velvele-i Rûm, tantana-i Rum oldu.” demektedir. Evliya Çelebi Çelebi Seyahatnâmesi, YKY, s.51. 
İstanbul'un merkez semtlerinden Süleymaniye, Vefa yakınında Vezneciler, Zeyrek, Fatih ve Çarşamba ulema semtleri diye adlandırılabilir. Bu semtlerin muteber mahaller olduğunu varsayabiliriz. Sebebi ise, II. Mehmed, Fatih Camii çevresinde Sahn-1 Seman medresesi yaptırmıştır. Burayı bitiren kimseler Süleymaniye medresesini ikmal ettikten sonra sınavla İstanbul ruusu alırlard1. İstanbul'da kadı, müderris olabilmek için buradan alınan ruus aranırdı. Söz konusu ruusu almayanlar gerçek anlamda tahsilli ve terbiyeli sayılmazlardı. Dolayısıyla bu semtlerin civarında da buna yönelik hayat tarzı oluşmuştur. Talebeler burada yatar ve kalkarlar ve Müderrisler burada ders vermeye gelirdi. Bazen ahali de bu kişileri dinlerdi. Fatih Camisi’nde görevi başında ölen sadrazamların cenazesi kılınırdı. Sadrazamların ve bazı büyük âlimlerin mezarları da bu haziredeydi. ${ }^{3}$ Süleymaniye'de devletin zengin ve tahsilli bürokratları ahşap konaklarda yaşardı. Camii, medrese, mescitler ve mezarlıkları yanında imaretiyle meşhurdu. Seyyahlar Süleymaniye imaretinin güzelliği ve dağıtılan yemeği methetmişlerdir. ${ }^{4}$ Aynı şekilde Soğan Ağa Mahallesi, İstanbul'da imparatorluk sarayına uzanan Divan Yolu üzerinde devlet ricali, yüksek memur, saraylı ve sarayla irtibatı olanlar, çeşitli iş sahipleri, tüccar ve devrin önde gelenlerinin ve zengin kesimin oturduğu kibar mahallesidir. XIX. yüzyılda reisülküttaplardan Râşid ve Gâlib Efendilerin ve İbrahim Kethüdanın haneleri burada bulunmaktayd ${ }^{5}$

Fatih Camii etrafında yer alan Eski İmaret Mahallesi de devlet ricali, yüksek memurlar (valiler, kazasker) ve ulemanın oturduğu bir mahalledir. Mesela XVIII. yüzyılın ilk yarısında Kudüs Kadısı Handanzâde Abdülbaki'nin konağı bu mahalledeydi. ${ }^{6} \mathrm{Bu}$ yerlerin XVII. yüzyılda aynı işleve sahip olduğunu görmekteyiz. Evliya Çelebi devlet ileri gelenlerinin saraylarını ve bulunduğu yerleri belirtirken buraların At Meydanı ve Ayasofya'dan Edirnekapı'ya giden Divan Yolu'ndaki mahaller ile Mahmutpaşa, Bayezıt Camii, Vefa arasındaki yerleşim alanlarında yer aldıklarından bahsetmektedir. ${ }^{7}$ Fakat buralar tamamen zengin kişilerin yaşadığı mahalleler olarak algılanmamalıdır. Çünkü toplumsal bir ayrım söz konusu değildi. Öncelikle ileri

3 İlber Ortaylı, “İstanbul'da Tarihi Yaşamak”, Şehir ve Kültür İstanbul, İstanbul; Profil yay, 2011, s.85.

4 Ortaylı, “İstanbul'da Tarihi Yaşamak”, ss.86-87.

5 Kemal Beydilli, Osmanlı'da Imamlar ve Bir Imamın Günlüğ̈̈, İzmir; Yitik Hazine Yay., 2013, s.87.

6 BabŞS 157-166a/2 (H. 7 Ra 1146/ M.18 Ağustos 1733). 1146 tarihli bu kayıt yukarıda ifade etiğimiz durumla örtüşmektedir. Sözü edilen Eski İmaret Mahallesinde fetihten beri devlet ricali, yüksek rütbeli memurlar, saraylılar ulema mensubu kişiler oturmaktadır. Ancak 18. yüzyılın ilk yarısında buraları satın alan kimselerin buralarda bekâr odaları yapmaya çalışması şikâyetlere sebep olmuştur. Mahalle sakinleri bu kimselere bina ve dükkân yapmaları için izin verilmeyerek mahalleden çıkarılmalarını talep etmişlerdir.

7 Evliya Çelebi, Seyahatname, C.I, ss.153-154; Mantran, 17. yy'da İstanbul, s.43. 
gelenlerin oturdukları konaklar, konut sahibinin evi ile birlikte hizmetçilerin (köle ve cariyeler) ve maiyetindeki herkesin evini kapsıyordu. Ayrıca bu mahallerin çoğunda sıradan olarak nitelendirilen halka ait küçük ölçekli evler de bulunuyordu. ${ }^{8}$

Şehrin fiziksel büyümesi, yeni kurulan mahalleler aracılığıyla gerçekleşir. Çünkü Osmanlı'da kent, mahalle mahalle inşa edilirdi. Başkent İstanbul'da artan nüfusa bağlı olarak yeni bir mahalle ortaya çıkmasıyla kent büyürdü. Mahallenin bu şekilde fiziksel yapılanmasında keyfilik söz konusu değildi. Yani bir bir mahallenin oluşması, bölünmesi ya da başka bir mahallenin sınırlarına dâhil edilmesi yetkisi devlete aittir. ${ }^{9}$ Kalifiye nüfusun iskânı çerçevesinde çoğunluğu oluşturan Müslüman ve Hıristiyan ahali genellikle ayrı mahalleler kuracak şekilde yerleştirilmiştir. Müslüman mahalleleri cami ya da mescitlerin etrafinda oluşurken, gayrimüslim mahalleleri kendi ibadethanelerine kilise ve havralara- yakın yerlere konumlanmışlardı. Ancak zamanla aynı mahalleleri paylaştıkları da olmuştur. Bu da mahalle kültürünün doğmasına yol açmıştır. Müslüman mahallelerin yanında Hıristiyan ve Yahudi mahallelerin kurulması Kanuni devrinde de devam etmiştir. XVI. yüzyılın ikinci yarısından itibaren gayrimüslimlerin yeni mahalle kurmasına izin verilmeyerek mevcut mahallelerde iskân edilmeye çalışıldığı görülmektedir. ${ }^{10}$ Kuruluş döneminde 182 olan mahalle sayısı Kanuni Döneminde yapılan bir sayıma göre 219'a yükselmiştir.

Nüfus XVI. yüzyılda İstanbul kentinin sorunlarından biriydi. Kentin imkânları ve iskâna açılmamış boş araziler olması başkenti bir cazibe merkezi yapmıştır. Şehir surlarının tamir edilmesi ve imar faaliyetleri sur içi mahallelerin oluşumunu hızlandırmıştır. 1635 yılında İstanbul'daki mahalle sayısının 292'ye yükselmiş olması bunun doğal bir sonucu olarak görülebilir. $\mathrm{Bu}$ mahalleler 12 cemaat tarafindan paylaşılmaktadır. ${ }^{11}$

8 Mantran, 17. yy'da İstanbul, s.43.

9 Suat Çabuk-Kemal Demir, "Osmanlı Kentlerinde Mahallelerin Mekânsallaştırılabilmesi İçin Bir Yöntem Denemesi: Kayseri Örneği”, Tarih Kültür ve Sanat Araştırmaları Dergisi, Vol.1 No.3, September 2012, s.141.

10 Ekrem Işın, İstanbul'da Gündelik Hayat, İstanbul; YKY, 2006, s.20.

11 Münir Aktepe, "XVII. Asra Ait İstanbul Kazası Avarız Defteri”, İstanbul Enstitüsü Dergisi, III, İstanbul 1957, s.114. 
İstanbul'un çekiciliği kente göçleri arttırmış olmalıdır ki XVI. ve XVII. yüzyıllarda İstanbul'a yapılan göçleri kısıtlamak amacıyla bir dizi önlem alınacaktır. ${ }^{12}$ Alınan tedbirler başarılı sonuçlar verecek ve İstanbul'daki mahalle sayısı artmayıp biraz düşecektir. 1672'de 253 Müslüman ve gayrimüslim mahallesi bulunmaktadır. Evliya Çelebi’nin XVII. yüzyıl İstanbul betimlemesinde dört mevleviyet hükümette 670 kaza ve 9.990 Müslüman mahallesi, 354 Rum mahallesi, 257 Yahudi mahallesi, 27 Ermeni mahallesi ve 17 Frenk mahallesi olduğunu söylemektedir. ${ }^{13}$ On bin Müslüman mahallesine karşılık bin gayrimüslim mahallesi oranına kuşkuyla bakmak gerekmektedir. ${ }^{14}$ Evliya Çelebi’nin mahalle anlayışının belirsizliğinden dolayı bu sayıyı doğru kabul etmek mümkün değildir.

XVIII. yüzyılın ilk yarısında şer‘iye sicillerindeki kayıtlardan yararlanarak yaptığımız çalışmaya göre sur içi İstanbul'daki mahalle sayısı 262 olarak tespit edilmiştir. $\mathrm{Bu}$ sayının yüzyılın yarısında kısmen düştüğü görülmektedir. Yerleşim birimlerindeki bu gerileyiş nüfus yoğunluğunun azalmasından ziyade daha çok idarî düzenlemelere bağlanabilir. Küçük yerleşimlerin kimisi zamanla daha büyük mahallelerin sınırları içine alınmıştır. İstanbul'un mahalle ölçüsünde belirli bölgelere ayrılma karakteri gösterdiği bu tür parçalanma ve eklemlemelerle gündelik hayatı sürdürdüğü söylenebilir. Nitekim kentin dinamik işleve sahip kimi yerleri özellikle Haliç ve bedesten çevresindeki ticarî faaliyetlerin yoğun olduğu mahallelerin ikincil yerleşimleri bünyelerine katarak genişledikleri görülmektedir. ${ }^{15}$

Nüfusun büyük çoğunluğu camiler etrafındaki mahaller ile ticaret merkezlerinin, çarşı-semt pazarlarının yer aldığı yerlerde ve kıyıya yakın yerlerde toplanmıştır. Çünkü buralar yoğun ekonomik faaliyetlerin yapıldığı cazibe merkezleridir. Nüfusun büyük yoğunlukta olduğu yerlere bakılırsa, sahil kısmında Haliç boyunca ve kentin Edirnekapı- Bayezıt hattının kuzeyinde, diğer yandan da Yenikapı, Aksaray, Şehzade Camii, Atmeydanı ve Marmara kıyıları arasındaki bölgeler olduğu görülür. ${ }^{16}$ Çarşı ve pazarlar belirtilen yerleşim alanları içinde kalmaktadır. Eminönü’ndeki Valide Sultan Camii'nin ön tarafında Eminönü İskelesi bulunmaktadır. Burada her türlü balık, meyve

12 18. yüzyıl İstanbul nüfusu ve İstanbul'a yönelik göçler için detaylı bilgi Münir “Aktepe, XVIII. Asrın Ilk Yarısında İstanbul Nüfus Mes'elesine Dâir Bâzı Vesikalar'.

13 Evliya Çelebi, Seyahatname, 1. Kitap, Topkapı Sarayı Kütüphanesi 304 Numaralı Yazmanın Transkiripsiyon- Dizin, YKY, haz. R. Dankoff- S.A. Kahraman- Y. Dağl1, İstanbul 2006, s.155.

14 Mantran, Istanbul Tarihi, s.244.

15 Işın, İstanbul'da Gündelik Hayat, s. 37.

16 Mantran, 17. yy'da İstanbul, s.43. 
ve sebze satılmaktadır. Bayezıt Camii civarı her türlü sanat ve meslek erbabının bulunduğu bir yerdir. ${ }^{17}$ Paraların basıldığı darphane, vezneciler ve itırcılar yine Beyazıt Camii civarında yer almaktadır. Valide Sultan Camii, Mısır Çarşısı ve Ketenciler Çarşısı da Eminönü semtindedir. Dört bir yanı çarşı pazar olan Fatih Camii'nin avlusu, her türlü eşyanın açıkta satıldığı bir yerdir. Fatih Camii civarı oldukça kalabalıktır, buralar alışverişe gelen insanlarla dolup taşmaktadır. Bu açıdan yerleşim alanlarının ekonomik canlılı̆̆ın olduğu çarşılar ve Pazarlar etrafında yoğunlaşması doğal görünmektedir.

Bunların dışında üçüncü yoğun yerleşim alanı Samatya ile Yedikule arasında uzanan bölgede yer alır. Burası her iki cemaate ait kiliselerin tanıklık ettiği üzere, Rum ve Ermenilerin çoğunlukta olduğu bölgedir. ${ }^{18}$

\section{Sur İçi İstanbul Mahalleleri}

H.1119-H.1146 (M.1707/8-M.1732/1733) tarihleri arasında incelenen kadı sicillerinden edindiğimiz bilgilere göre XVIII. yüzyılın ilk yarısında adı geçen mahalleler şunlardır:

Tablo 1

1708-1732 tarihleri arasında İstanbul Tarihi Yarımada Mahalleleri ${ }^{19}$ (Kadı Sicillerine Göre)

\begin{tabular}{|c|c|c|c|c|c|}
\hline & & & & 2. GRUF & \\
\hline & & 1. GRUP & & rimüslir & \\
\hline & & Müslüman & Ermeni & Yahudi & Rum \\
\hline 1 & Abdi Çelebi Mahallesi & $\mathrm{X}$ & $\mathrm{X}$ & $\mathrm{X}$ & $\mathrm{X}$ \\
\hline 2 & Abdi Subaşı Mahallesi 20 & $\mathrm{X}$ & $\mathrm{X}$ & $\mathrm{X}$ & $\mathrm{X}$ \\
\hline 3 & Abdullah Ağa Mahallesi & $\mathrm{X}$ & & & \\
\hline 4 & Ahmed Dede Mahallesi & $\mathrm{X}$ & & & \\
\hline 5 & Akbıyık Mahallesi & $\mathrm{X}$ & & & \\
\hline
\end{tabular}

17 “Azîm iskele bu Camîin önüdür. Deryâdan ne dürlü canavar var ise ele gireni bunda getirürler ve limon ve turunc ve nar ve ağaç, kavunu ve her gûne meyve ve her dürlü çiçek anda mevcûddur”. Beyazıt Camii için, "Ne kadar hatem kazıcı ve ne kadar kaşıkçı ve ne kadar bıçakçı ve ne kadar sermeci ve ne kadar kafes-dâr elhasıl cümlesi esnaftan ve pide bazarı ve bakırcı ve bardak ve küp satanlar cümlesi cami-i şerifin cevânib-i erbaasında doludur...” Resmî Kayseri, Seyahat-nâme, s.153a; Bahir Selçukİ. Halil Tuğluk, "Bir Mecmuanın Işı̆̆ında...”, s.221.

18 Mantran, 17. yy'da İstanbul, s.44.

19 Sur içi İstanbul ya da Tarihî Yarımada olarak adlandırılan bölge; Bizans surları, kuzeyde Haliç, doğuda İstanbul Boğazı ve güneyde Marmara Denizi ile çevrili kısımdır. Günümüzde bu bölge Fatih semtinin sınırları içerisinde yer almaktadır.

20 Fener kapısı haricindedir. 


\begin{tabular}{|c|c|c|c|c|c|}
\hline 6 & Aksaray Mahallesi & $\mathrm{X}$ & & & \\
\hline 7 & Akseki Mahallesi & $\mathrm{X}$ & & & \\
\hline 8 & Akşemseddin Mahallesi & $\mathrm{X}$ & & & \\
\hline 9 & Ali Beğ Cami-i Şerifi Mah. ${ }^{21}$ & $\mathrm{X}$ & & & \\
\hline 10 & Ali Fakih Mahallesi & $\mathrm{X}$ & & & \\
\hline 11 & Ali Paşa Mahallesi ${ }^{22}$ & $\mathrm{X}$ & & & \\
\hline 12 & Ali Paşa-yı Atik Mahallesi ${ }^{23}$ & $\mathrm{X}$ & $\mathrm{X}$ & $\mathrm{X}$ & $\mathrm{X}$ \\
\hline 13 & Altı Poğaça Mahallesi & $\mathrm{X}$ & & & \\
\hline 14 & Arabacı Bayezıd Mahallesi & $\mathrm{X}$ & & & \\
\hline 15 & Arpa Emini Mahallesi ${ }^{24}$ & $\mathrm{X}$ & & & \\
\hline 16 & Âşıı Paşa Mahallesi & $\mathrm{X}$ & & & \\
\hline 17 & Avcibey Mahallesi & $\mathrm{X}$ & $\mathrm{X}$ & $\mathrm{X}$ & $\mathrm{X}$ \\
\hline 18 & Ayasofya-yı Kebîr Mahallesi & $\mathrm{X}$ & & & \\
\hline 19 & Ayasofya-yı Sagîr Mahallesi ${ }^{25}$ & $\mathrm{X}$ & & & \\
\hline 20 & Aydın Kethüda Mahallesi ${ }^{26}$ & $\mathrm{X}$ & $\mathrm{X}$ & & $\mathrm{X}$ \\
\hline 21 & Azablar Mahallesi & $\mathrm{X}$ & & & \\
\hline 22 & Baba Hasan Âlemi Mahallesi & $\mathrm{X}$ & & & \\
\hline 23 & Baklalı Mahallesi & $\mathrm{X}$ & & & \\
\hline 24 & Balaban Ağa Mahallesi & $\mathrm{X}$ & & & \\
\hline 25 & Balcı Mahallesi $^{27}$ & $\mathrm{X}$ & & & \\
\hline 26 & Bali Paşa Mahallesi & $\mathrm{X}$ & & & \\
\hline 27 & Bayezıd Ağa Mahallesi $^{28}$ & $\mathrm{X}$ & $\mathrm{X}$ & & $\mathrm{X}$ \\
\hline 28 & Bazargan Mahalesi & $\mathrm{X}$ & $\mathrm{X}$ & $\mathrm{X}$ & $X$ \\
\hline 29 & Beğceğiz Mahallesi & $\mathrm{X}$ & & & \\
\hline 30 & Bıçakçı Mahallesi & $\mathrm{X}$ & & & \\
\hline 31 & Bıyıklı Mescid Mahallesi & $\mathrm{X}$ & & & \\
\hline 32 & Bostancıbaşı Ali Ağa Mah. & $\mathrm{X}$ & & & \\
\hline 33 & Bucakbağı Mahallesi & $\mathrm{X}$ & & & \\
\hline 34 & Burmalı Mescid Mahallesi & $\mathrm{X}$ & & & \\
\hline 35 & Cafer Ağa Mahallesi & $\mathrm{X}$ & & & \\
\hline 36 & Cambaziye Mahallesi & $\mathrm{X}$ & & & \\
\hline 37 & Camcı Ali Mahallesi & $\mathrm{X}$ & & & \\
\hline 38 & Cebecibaşı Mahallesi & $\mathrm{X}$ & & & \\
\hline 39 & Cerrah İshak Mahallesi & $\mathrm{X}$ & $\mathrm{X}$ & $\mathrm{X}$ & $X$ \\
\hline 40 & Çadırcı Ahmet Mahallesi & $\mathrm{X}$ & $\mathrm{X}$ & & $\mathrm{X}$ \\
\hline 41 & Çakır Ağa Mahallesi & $\mathrm{X}$ & $\bar{X}$ & $\mathrm{X}$ & $\mathrm{X}$ \\
\hline 42 & Çavuşbaşı Mahallesi $^{29}$ & $\mathrm{X}$ & & & \\
\hline 43 & Çayzade Mahallesi & $\mathrm{X}$ & & & \\
\hline
\end{tabular}

21 Mahallenin ismi 88 numaralı Bab Mahkemesi Şer'iyye Sicilinde geçmiştir. Ali Paşa Mahallesi bu sicilde geçmediğinden muhtemelen Ali Paşa Mahallesi olarak kullanıllmıştır.

22 Kıptilerin yaşadığı diğer bir mahalledir.

23 Diğer bir kullanımı Atik Ali Mahallesi'dir.

Bazı kayıtlarda Arpa Emini Sinan Ağa Mahallesi ya da Arpacı Sinan Mahallesi olarak da adlandırılmıştır.

25 Küçük Ayasofya Mahallesi olarak da kaydedilmişstir.

26 Mahallede Kıptilerde iskân edilmiştir.

27157 Numaralı sicilde ilk kez adı geçmektedir.

28 Mahallede Kiptiler de yaşamaktadır.

29105 Numaralı sicilde Çavuş Mescidi Mahallesi adıyla bir mahalle kaydedilmiştir. İki farklı isimle kaydedilmiş olmakla beraber aynı mahalledir. 


\begin{tabular}{|c|c|c|c|c|c|}
\hline 44 & Çelebi oğlu Mahallesi & $\mathrm{X}$ & & & \\
\hline 45 & Çerağ Hamza Mahallesi & $\mathrm{X}$ & & & \\
\hline 46 & Çerağ Hasan Mahallesi & $\mathrm{X}$ & & & \\
\hline 47 & Çıkrıkçı Kemal Mahallesi ${ }^{30}$ & $\mathrm{X}$ & & & \\
\hline 48 & Çoban Çavuş Mahallesi & $\mathrm{X}$ & $\mathrm{X}$ & $\mathrm{X}$ & $\mathrm{X}$ \\
\hline 49 & Çorbacı Salih Ağa Mahallesi & $\mathrm{X}$ & & & \\
\hline 50 & Çukur Bostan Mahallesi & $\mathrm{X}$ & $\mathrm{X}$ & $\mathrm{X}$ & $\mathrm{X}$ \\
\hline 51 & Davut Paşa Mahallesi & $X$ & & & \\
\hline 52 & Daye Hatun Mahallesi & $X$ & & & \\
\hline 53 & Debbağ Yunus Mahallesi & $\mathrm{X}$ & & & \\
\hline 54 & Debbağzade Hacı Piri Mah. & $\mathrm{X}$ & & & \\
\hline 55 & Defterdar Ahmet Çelebi Mah. & $\mathrm{X}$ & & & \\
\hline 56 & Deniz Abdal Mahallesi & $\mathrm{X}$ & & & \\
\hline 57 & Derviş Ali Mahallesi & $\mathrm{X}$ & & & \\
\hline 58 & Divane Ali Mahallesi & $X$ & $\mathrm{X}$ & $\mathrm{X}$ & $\mathrm{X}$ \\
\hline 59 & Dizdariye Mahallesi & $\mathrm{X}$ & & & \\
\hline 60 & Dudu (Tuti) Abdullatif Mah. & $\mathrm{X}$ & & & \\
\hline 61 & Dülbentçi Hüsam Mahallesi & $X$ & $\mathrm{X}$ & $\mathrm{X}$ & $\mathrm{X}$ \\
\hline 62 & Dülger zade Mahallesi & $\mathrm{X}$ & & & \\
\hline 63 & Efdalzade Mahallesi & $\mathrm{X}$ & & & \\
\hline 64 & El-hac Bayram ${ }^{31}$ Mahallesi & $\mathrm{X}$ & & & \\
\hline 65 & Elhac Hasan Mahallesi ${ }^{32}$ & $\mathrm{X}$ & & & \\
\hline 66 & Elhac Hüseyin Mahallesi & $X$ & $\mathrm{X}$ & & \\
\hline 67 & Elhac Hüsrev Mahallesi & $X$ & & & \\
\hline 68 & El-hac İlyas Mahallesi & $\mathrm{X}$ & & & \\
\hline 69 & Elhac İsa Mahallesi & $\mathrm{X}$ & $X$ & $\mathrm{X}$ & $X$ \\
\hline 70 & Elhac Muhiddin ${ }^{33}$ Mahallesi & $\mathrm{X}$ & $\mathrm{X}$ & $\mathrm{X}$ & $\mathrm{X}$ \\
\hline 71 & Elhac Piri Mahallesi & $\mathrm{X}$ & $\mathrm{X}$ & $X$ & $\mathrm{X}$ \\
\hline 72 & El-hac Timur Mahallesi & $\mathrm{X}$ & $\mathrm{X}$ & $\mathrm{X}$ & $\mathrm{X}$ \\
\hline 73 & Elvan zade Mahallesi & $\mathrm{X}$ & & & \\
\hline 74 & Emin Beğ Mahallesi $^{34}$ & $\mathrm{X}$ & & & \\
\hline 75 & Emin Nureddin Mahallesi & $\mathrm{X}$ & & & \\
\hline 76 & Emincu Mahallesi & $\mathrm{X}$ & & & \\
\hline 77 & Emir Buhari Mahallesi & $\mathrm{X}$ & & & \\
\hline 78 & Ereğli Mahallesi & $\mathrm{X}$ & & & \\
\hline 79 & Esirci Kemal Mahallesi & $\mathrm{X}$ & & & \\
\hline 80 & Eski İmaret Mahallesi & $\mathrm{X}$ & & & \\
\hline 81 & Evliya Mehmet Efendi Mah. & $\mathrm{X}$ & & & \\
\hline 82 & Fatma Sultan Mahallesi & $\mathrm{X}$ & $\mathrm{X}$ & $\mathrm{X}$ & $\mathrm{X}$ \\
\hline 83 & Fenarî Hamid Paşa Mahallesi & $\mathrm{X}$ & & & \\
\hline 84 & Fenâyi Dede Mahallesi & $\mathrm{X}$ & & & \\
\hline
\end{tabular}

157 Numaralı Bab Sicilinde geçmektedir.

Elhac Bayram Kaftanî Mahallesi olarak da geçmektedir.

Diğer bir kullanımı Elhac Hasanzade Mahallesi’dir.

El-Şeyh Muhiddin Kocavî Mahallesi olarak da kullanılmaktadır. BabŞS 109- 116-117a-b 24 Ra 1127.

34 Emin Sinan Mahallesi’nin de aynı mahalle olduğu düşünülmektedir. 


\begin{tabular}{|c|c|c|c|c|c|}
\hline 85 & Fethiye Mahallesi & $\mathrm{X}$ & & & \\
\hline 86 & Firuz Ağa Mahallesi & $\mathrm{X}$ & & & \\
\hline 87 & Gazi Sinan Paşa Mahallesi & $\mathrm{X}$ & & & \\
\hline 88 & Gedik Paşa Mahallesi & $\mathrm{X}$ & $\mathrm{X}$ & & $\mathrm{X}$ \\
\hline 89 & Gureba Hüseyin Ağa Mahallesi & $\mathrm{X}$ & & & \\
\hline 90 & Gül Cami-i Şerifi Mahallesi & $\mathrm{X}$ & $\mathrm{X}$ & & $\mathrm{X}$ \\
\hline 91 & Güngörmez Mahallesi & $\mathrm{X}$ & & & \\
\hline 92 & Hâce Kadı ${ }^{35}$ Mahallesi & $\mathrm{X}$ & $\mathrm{X}$ & $\mathrm{X}$ & $\mathrm{X}$ \\
\hline 93 & Hamamcı Muhiddin Mahallesi & $X$ & $\mathrm{X}$ & $\mathrm{X}$ & $\mathrm{X}$ \\
\hline 94 & Haraççı Muhiddin Mahallesi & $\mathrm{X}$ & & & \\
\hline 95 & Harem Cavus Mahallesi & $\mathrm{X}$ & & & \\
\hline 96 & Hasan Paşa-yı Atik Mahallesi ${ }^{36}$ & $\mathrm{X}$ & & & \\
\hline 97 & Hasırc1 Mahallesi & $\mathrm{X}$ & & & \\
\hline 98 & Hassa Kadın Mahallesi & $\mathrm{X}$ & & & \\
\hline 99 & Hatice Sultan Mahallesi & $\mathrm{X}$ & & & \\
\hline 100 & Havuzlu Mescid Mahallesi & $\mathrm{X}$ & & & \\
\hline 101 & Haydar Paşa Mahallesi & $\mathrm{X}$ & & & \\
\hline 102 & Hirat Kemal Mahallesi & & & & \\
\hline 103 & Hızır Beğ Mahallesi & $\mathrm{X}$ & & $\mathrm{X}$ & \\
\hline 104 & Hobyar Mahallesi & $\mathrm{X}$ & & & \\
\hline 105 & Hoca Dursun Mahallesi & $\mathrm{X}$ & & & \\
\hline 106 & Hoca Evis (Veyis) Mahallesi & $\mathrm{X}$ & & & \\
\hline 107 & Hoca Hamza Mahallesi & $\mathrm{X}$ & & & \\
\hline 108 & Hoca Hayreddin Mahallesi & $\mathrm{X}$ & & & \\
\hline 109 & Hoca Hüseyin zade Mahallesi & $\mathrm{X}$ & & & \\
\hline 110 & Hoca Kasım Günanî Mahallesi & $\mathrm{X}$ & & & \\
\hline 111 & Hoca Küçük Mahallesi & $\mathrm{X}$ & & $\mathrm{X}$ & \\
\hline 112 & Hoca Paşa Mahallesi & $\mathrm{X}$ & & & \\
\hline 113 & Hoşkadem Mahallesi & $X$ & & & \\
\hline 114 & Hüsam Beğ Mahallesi & $\mathrm{X}$ & & & \\
\hline 115 & Hüseyin Ağa Mahallesi & $\mathrm{X}$ & & & \\
\hline 116 & İbn-i Meddas Mahallesi & $\mathrm{X}$ & & & \\
\hline 117 & İbrahim Çavuş Mahallesi & $\mathrm{X}$ & & & \\
\hline 118 & İbrahim Paşa-yı Atik Mahallesi & $\mathrm{X}$ & $\mathrm{X}$ & & $\mathrm{X}$ \\
\hline 119 & İç Doğan Mahallesi & $\mathrm{X}$ & & & \\
\hline 120 & İdris Beğ Mahallesi ${ }^{37}$ & $\mathrm{X}$ & & & \\
\hline 121 & İlyas Efendi Mahallesi ${ }^{38}$ & $\mathrm{X}$ & & & \\
\hline 122 & İmam Ali Mahallesi & $\mathrm{X}$ & & & \\
\hline 123 & İne Bey Mahallesi ${ }^{39}$ & $\mathrm{X}$ & $\mathrm{X}$ & $\mathrm{X}$ & $\mathrm{X}$ \\
\hline 124 & İshak Beğ Mahallesi & & $\mathrm{X}$ & & \\
\hline 125 & İskender Ağa (Paşa) Mahallesi & $\mathrm{X}$ & & & \\
\hline 126 & İslam Beğ Mahallesi & & & & $\mathrm{X}$ \\
\hline
\end{tabular}

35 Hâce Hatun ya da Hatuniyye Mahallesi olarak ta geçmektedir.

3 Hasan Halife Mahallesi olarak da yazılmıştır.

139 Numaralı Sicilde adı geçmektedir.

8 İlyaszade Mahallesi olarak da geçmektedir.

39 İne Hayreddin diğer bir kullanımı. 


\begin{tabular}{|c|c|c|c|c|c|}
\hline 127 & İsmail Ağa Mahallesi & $\mathrm{X}$ & & & \\
\hline 128 & Kaba Kulak Mahallesi & $\mathrm{X}$ & & & \\
\hline 129 & Kaba Sakal (Sinan Ağa) Mah. & $\mathrm{X}$ & & & \\
\hline 130 & Kalenderhane Mahallesi & $\mathrm{X}$ & & & \\
\hline 131 & Kaliçeci Hasan Mahallesi & $\mathrm{X}$ & & & \\
\hline 132 & Kap1 Ağası Mahmut Ağa Mah. & $\mathrm{X}$ & & & \\
\hline 133 & Kapudan Sinan Ağa Mahallesi & $X$ & & & \\
\hline 134 & Karabaş Mahallesi & $X$ & $\mathrm{X}$ & $\mathrm{X}$ & \\
\hline 135 & Karaki Hüseyin Çelebi Mah. ${ }^{40}$ & $\mathrm{X}$ & & & \\
\hline 136 & Kasap İlyas Mahallesi & $\mathrm{X}$ & $\mathrm{X}$ & & \\
\hline 137 & Kasap İvaz Mahallesi & $\mathrm{X}$ & & & \\
\hline 138 & Kasap Timur (Demirhan) Mah. & $\mathrm{X}$ & & & \\
\hline 139 & Kasım Paşa Mahallesi & $\mathrm{X}$ & $\mathrm{X}$ & & $\mathrm{X}$ \\
\hline 140 & Kâtip Hüsrev Mahallesi & $X$ & & & \\
\hline 141 & Kâtip Kasım Mahallesi & $\mathrm{X}$ & $\mathrm{X}$ & $\mathrm{X}$ & $\mathrm{X}$ \\
\hline 142 & Kâtip Murad Mahallesi & $\mathrm{X}$ & & & \\
\hline 143 & Kâtip Musluhiddin Mahallesi & $\mathrm{X}$ & & & \\
\hline 144 & Kazasker Mehmed Efendi Mah & $\mathrm{X}$ & & & \\
\hline 145 & Kazganî Sa'di (Kangancı) & $\mathrm{X}$ & $X$ & $\mathrm{X}$ & $\mathrm{X}$ \\
\hline 146 & Kazlı Çeşme Mahallesi & $X$ & & & \\
\hline 147 & Keçeci Piri Mahallesi & $X$ & $X$ & $\mathrm{X}$ & $X$ \\
\hline 148 & Kefeli Mahallesi & $\mathrm{X}$ & $\mathrm{X}$ & $\mathrm{X}$ & $\mathrm{X}$ \\
\hline 149 & Kemal Paşa Mahallesi & $\mathrm{X}$ & & & \\
\hline 150 & Kemanî Kara Mustafa Paşa M. & $\mathrm{X}$ & & & \\
\hline 151 & Kemankeş Ahmet Ağa Mah. $^{41}$ & $\mathrm{X}$ & & & \\
\hline 152 & Kepenekçi Sinan Mahallesi & $\mathrm{X}$ & & & \\
\hline 153 & Keskin Dede Mahallesi & $\mathrm{X}$ & & & \\
\hline 154 & Kethüda Hatun Mahallesi $^{42}$ & $\mathrm{X}$ & & & \\
\hline 155 & Keyci Hatun Mahallesi & & & & \\
\hline 156 & Kizıl Mescit Mahallesi & $\mathrm{X}$ & & & \\
\hline 157 & Kızıltaş Mahallesi & $\mathrm{X}$ & $\mathrm{X}$ & & $\mathrm{X}$ \\
\hline 158 & Kiremid Mahallesi & $\mathrm{X}$ & $X$ & $\mathrm{X}$ & $\mathrm{X}$ \\
\hline 159 & Kirmasti Mahallesi & $\mathrm{X}$ & $\mathrm{X}$ & $\mathrm{X}$ & \\
\hline 160 & Koca Mustafa Paşa Mah. & $\mathrm{X}$ & $\mathrm{X}$ & & \\
\hline 161 & Koğacı (Kovacı) Dede Mah. & $\mathrm{X}$ & & & \\
\hline 162 & Korucu Mehmed Çelebi Mah. & & $X$ & $\mathrm{X}$ & $\mathrm{X}$ \\
\hline 163 & Koruk Mahmud Mahallesi & $\mathrm{X}$ & & & \\
\hline 164 & Kulaksız Mahallesi & & $\mathrm{X}$ & $\mathrm{X}$ & $\mathrm{X}$ \\
\hline 165 & Kuyumcu Bahşayiş Mahallesi & $X$ & & & \\
\hline 166 & Kürkçübaşı Elhac Hüseyin M. & $\mathrm{X}$ & $\mathrm{X}$ & $\mathrm{X}$ & $\mathrm{X}$ \\
\hline 167 & Kürkçübaşı Süleyman Ağa M. & $\mathrm{X}$ & $\mathrm{X}$ & $\mathrm{X}$ & $\mathrm{X}$ \\
\hline 168 & Lalezâr Mahallesi & $X$ & & & \\
\hline
\end{tabular}

40 Başlarda Karaki Mahallesi olarak kullanılırken daha sonra Karakî Hüseyin Çelebi Mahallesi olarak kayıt edilmiştir. Bkz. BabŞS Nu. 94, 135.

41 BabŞS 109-117a/ (24 Ra1127/29 Nisan 1715).

42 Karagümrük civarındadır ve Müslümanlar meskûndur. BabŞS. Nu. 91. 


\begin{tabular}{|c|c|c|c|c|c|}
\hline 169 & Lütfi Paşa Mahallesi & $\mathrm{X}$ & & & \\
\hline 170 & Mağnisalı Çelebi Mahallesi ${ }^{43}$ & $\mathrm{X}$ & & & \\
\hline 171 & Mahmut Paşa Mahallesi & $\mathrm{X}$ & & & \\
\hline 172 & Melek Hatun Mahallesi & $\mathrm{X}$ & & & \\
\hline 173 & Mercan Ağa Mahallesi & $\mathrm{X}$ & & & \\
\hline 174 & Mesih Paşa Mahallesi & $\mathrm{X}$ & & & \\
\hline 175 & Mimar Ayas Mahallesi & $\mathrm{X}$ & & & \\
\hline 176 & Mimar Sinan Mahallesi & $\mathrm{X}$ & & & \\
\hline 177 & Mirahor Mahallesi & $\mathrm{X}$ & $\mathrm{X}$ & $\mathrm{X}$ & \\
\hline 178 & Molla Ahvin Mahallesi* & $\mathrm{X}$ & & & \\
\hline 179 & Molla Ali Fenârî Mahallesi & $\mathrm{X}$ & & & \\
\hline 180 & Molla Aşki Mahallesi & $\mathrm{X}$ & & & $\mathrm{X}$ \\
\hline 181 & Molla Gürânî Mahallesi & $\mathrm{X}$ & & & \\
\hline 182 & Molla Hüsrev Mahallesi & $\mathrm{X}$ & & & \\
\hline 183 & Molla Kesdel Mahallesi & $\mathrm{X}$ & & & \\
\hline 184 & Molla Şeref Mahallesi & $\mathrm{X}$ & & & \\
\hline 185 & Muhsine Hatun Mahallesi & $\mathrm{X}$ & $\mathrm{X}$ & $\mathrm{X}$ & $\mathrm{X}$ \\
\hline 186 & Muhtesip İskender Mahallesi & $\mathrm{X}$ & & & \\
\hline 187 & Murat Paşa Mahallesi & $\mathrm{X}$ & & & \\
\hline 188 & Mustafa Beğ (Dühani)Mah. & $\mathrm{X}$ & & & \\
\hline 189 & Mustafa Paşa-yı Atik Mahallesi & $\mathrm{X}$ & $\mathrm{X}$ & $\mathrm{X}$ & $\mathrm{X}$ \\
\hline 190 & Müftü Ali Paşa Mahallesi ${ }^{44}$ & $\mathrm{X}$ & & & \\
\hline 191 & Müneccim Sa'di Mahallesi & $\mathrm{X}$ & & & \\
\hline 192 & Nahılbend (Nakilbent) Mah. & $\mathrm{X}$ & & & \\
\hline 193 & Nalçacı İbrahim Mahallesi & $\mathrm{X}$ & & & \\
\hline 194 & Nasuh Paşa Mahallesi & $\mathrm{X}$ & & & \\
\hline 195 & Neslişah Sultan Mahallesi & $\mathrm{X}$ & & & \\
\hline 196 & Nevbahar Mahallesi & $\mathrm{X}$ & & & \\
\hline 197 & Nişancı Mehmet Paşa Mah. & $\mathrm{X}$ & & & \\
\hline 198 & Nişancı Paşa Mahallesi ${ }^{45}$ & $\mathrm{X}$ & $\mathrm{X}$ & $\mathrm{X}$ & $\mathrm{X}$ \\
\hline 199 & Nuri Dede Mahallesi & $\mathrm{X}$ & & & \\
\hline 200 & Ohri Mahallesi & $\mathrm{X}$ & $\mathrm{X}$ & $\mathrm{X}$ & $\mathrm{X}$ \\
\hline 201 & Oruç Gazi Mahallesi & $\mathrm{X}$ & & & \\
\hline 202 & Öksüzce Mahallesi & $\mathrm{X}$ & & & \\
\hline 203 & Ördek Kasap Mahallesi & $\mathrm{X}$ & & & \\
\hline 204 & Papazoğlu Mahallesi $^{46}$ & $\mathrm{X}$ & & & \\
\hline 205 & Pirinçci Sinan Mahallesi & & & & \\
\hline 206 & Sahaf Süleyman Mahallesi & $\mathrm{X}$ & & & \\
\hline 207 & Salih Paşa Mahallesi & $\mathrm{X}$ & & & \\
\hline 208 & Saliha Hatun Mahallesi & $\mathrm{X}$ & & & \\
\hline 209 & Salma Tomruk Mahallesi & $\mathrm{X}$ & $\mathrm{X}$ & & $\mathrm{X}$ \\
\hline 210 & Saman Veren Mahallesi & $\mathrm{X}$ & & & \\
\hline 211 & Sancaktar Hayreddin Mahallesi & $\mathrm{X}$ & $\mathrm{X}$ & $\mathrm{X}$ & $\mathrm{X}$ \\
\hline
\end{tabular}

Kıptilerin yoğun olarak oturdukları mahalledir.

Müftü Ali Çelebi Mahallesi diğer bir kullanımıdır. BabŞS107-76a/11 (19 S1127/24 Şubat 1715).

45 Diğer bir kullanım Nişancı Paşa-yı Atik Mahallesi. BabŞS140 Numaralı sicil.

46 BabŞS 157 Numaralı sicilde ilk kez geçmektedir. 


\begin{tabular}{|c|c|c|c|c|c|}
\hline 212 & Saraç Doğan Mahallesi & $\mathrm{X}$ & & & \\
\hline 213 & Saraç İshak Mahallesi & $\mathrm{X}$ & $\mathrm{X}$ & $\mathrm{X}$ & $\mathrm{X}$ \\
\hline 214 & Sarı Bayezıd Mahallesi & $\mathrm{X}$ & & & \\
\hline 215 & Sar1 Musa Mahallesi ${ }^{47}$ & $\mathrm{X}$ & & & \\
\hline 216 & Sarı Nasuh Mahallesi & $\mathrm{X}$ & & & \\
\hline 217 & Sarıgez (Sarıgüzel) Mahallesi & $\mathrm{X}$ & & & \\
\hline 218 & Sarmaşık Mahallesi & $\mathrm{X}$ & & & \\
\hline 219 & Sekbanbaşı İbrahim Ağa Mah. & $\mathrm{X}$ & & & \\
\hline 220 & Serhobçu Mahallesi (?) & $\mathrm{X}$ & & & \\
\hline 221 & Seydi Halife Mahallesi & $\mathrm{X}$ & & & \\
\hline 222 & Seyyid Ömer Mahallesi & $\mathrm{X}$ & $\mathrm{X}$ & $\mathrm{X}$ & $\mathrm{X}$ \\
\hline 223 & Simkeş Mahallesi & $X$ & & & \\
\hline 224 & Sinan Ağa Mahallesi & $X$ & & & \\
\hline 225 & Sinan Beğ Mahallesi & $\mathrm{X}$ & & & \\
\hline 226 & Sivrikoz (Seferikoz) Mahallesi & $\mathrm{X}$ & & & \\
\hline 227 & Sofular Mahallesi & $\mathrm{X}$ & & & \\
\hline 228 & Soğan Ağa Mahallesi & $\mathrm{X}$ & & & \\
\hline 229 & Suhte (Softa) Sinan Mahallesi & $\mathrm{X}$ & & & \\
\hline 230 & Sultan Bayezit Cedit Mahallesi & $\mathrm{X}$ & & & \\
\hline 231 & Sulu Manastır Mahallesi & $\mathrm{X}$ & $\mathrm{X}$ & $\mathrm{X}$ & $\mathrm{X}$ \\
\hline 232 & Süleyman Ağa Mahallesi & $\mathrm{X}$ & $\mathrm{X}$ & & $\mathrm{X}$ \\
\hline 233 & Sülüklü Çeşme Mahallesi & $\mathrm{X}$ & & & \\
\hline 234 & Şah Huban Mahallesi & $\mathrm{X}$ & & & \\
\hline 235 & Şah Sultan Mahallesi & $\mathrm{X}$ & & & \\
\hline 236 & Şehsuvar Mahallesi & $\mathrm{X}$ & & & \\
\hline 237 & Şeyh Ebu'l-Vefa Mahallesi & $X$ & & & \\
\hline 238 & Şeyh Ferhad Mahallesi & $\mathrm{X}$ & $\mathrm{X}$ & $\mathrm{X}$ & $\mathrm{X}$ \\
\hline 239 & Şeyh Hasan Paşa Mahallesi & $\mathrm{X}$ & & & \\
\hline 240 & Tahta Minare Mahallesi & & $\mathrm{X}$ & $\mathrm{X}$ & $\mathrm{X}$ \\
\hline 241 & Takkeci Mahallesi & $\mathrm{X}$ & & & \\
\hline 242 & Tarsus Mahallesi $^{48}$ & $\mathrm{X}$ & & & \\
\hline 243 & Tavaşlı Süleyman Ağa Mah. & $\mathrm{X}$ & $\mathrm{X}$ & $\mathrm{X}$ & $\mathrm{X}$ \\
\hline 244 & Tercüman Yunus Mahallesi & $\mathrm{X}$ & & & \\
\hline 245 & Tevkiî Cafer Paşa Mahallesi $^{49}$ & $\mathrm{X}$ & $\mathrm{X}$ & $\mathrm{X}$ & $\mathrm{X}$ \\
\hline 246 & Timurhan Mahallesi & $\mathrm{X}$ & & & \\
\hline 247 & Toklu Dede Mahallesi & $\mathrm{X}$ & & & \\
\hline 248 & Toptaş Mahallesi & $\mathrm{X}$ & & & \\
\hline 249 & Türbe Kemal Mahallesi & $\mathrm{X}$ & & & \\
\hline 250 & Uzun Şüca' Mahallesi & $\mathrm{X}$ & & & \\
\hline 251 & Uzun Yusuf Mahallesi & $\mathrm{X}$ & & & \\
\hline 252 & Üskübî Mahallesi & $\mathrm{X}$ & & & \\
\hline
\end{tabular}

47 BabŞS 157 Numaralı Sicilde geçmektedir.

48 Aynı sicilde adı geçmektedir.

49 Nişancı Cafer Çelebi Mahallesi olarak da kullanılmıştır. 


\begin{tabular}{|c|c|c|c|c|c|}
\hline 253 & Voynuk Şüca' Mahallesi ${ }^{50}$ & $\mathrm{X}$ & & & \\
\hline 254 & Yahya Gözlü Mahallesi & $\mathrm{X}$ & & & \\
\hline 255 & Yakub Ağa Mahallesi & $\mathrm{X}$ & & & \\
\hline 256 & Yarhisar Mahallesi $^{51}$ & $\mathrm{X}$ & $\mathrm{X}$ & $\mathrm{X}$ & $\mathrm{X}$ \\
\hline 257 & Yavaşça Şahin Mahallesi & $\mathrm{X}$ & & & \\
\hline 258 & Yavezar (Yavuzlar) Mahallesi & $\mathrm{X}$ & & & \\
\hline 259 & Yeni Mahalle & & $\mathrm{X}$ & $\mathrm{X}$ & $\mathrm{X}$ \\
\hline 260 & Yildırım Mahallesi $^{52}$ & $\mathrm{X}$ & & & \\
\hline 261 & Zeyrek Mahallesi & $\mathrm{X}$ & & & \\
\hline 262 & Zeytin Mahallesi & & $\mathrm{X}$ & $\mathrm{X}$ & $\mathrm{X}$ \\
\hline
\end{tabular}

İstanbul'un mahalle bazında yerleşim bölgelerini ana hatlarıyla belirtmek gerekirse, Müslüman halk Fatih, Aksaray, Tophane, Cibali, Ayasofya, Eyüb’e iskân edilmişlerdir. Gayrimüslim cemaate gelince, Rumlar çoğu deniz kıyısında Samatya, Kumkapı, Balat, Fener ile Cibali arasındaki mahallelere yerleşmiştir. Evliya Çelebi Rumların özellikle denizcilik, balıkçılık ve meyhanecilik gibi mesleklerle meşgul olduklarını söylemektedir. Ermeni nüfusa gelince Sulumanastır başta olmak üzere Topkapı, Kumkapı, Lanka, Yenikapı ve Balat'a iskân edilmişlerdir. Edirnekapı civarında da Ermeni mahalleleri olduğu tespit edilmiştir. Yahudiler Sirkeci'den Balat'a kadar olan bölgedeki semtlerde (Bahçekapı, Yıldız hamamı, Balat, Ayvansaray) sakin olmuşlardır. Topkapı ve Balat'ta Rumlar, Ermeniler ve Yahudiler ile birlikte yaşamaktadır. Kadı sicillerindeki kayıtlardan da İstanbul Kalesi ve Eyüp’ten Balat, Fener, Cibali ve Unkapanı dâhil ve haricinde Yahudihanelerin mevcut olduğu anlaşılmaktadır. ${ }^{53}$

Müslüman ve gayrimüslimlerin İstanbul'da yaşadıkları semtlerin genel bir çerçevesi çizildikten sonra mahallelerdeki dağılıma baktığımızda, gayrimüslimlerin yoğun olarak yaşadığı Sur içi mahallelerinden biri “Abdi Çelebi” olarak zikredilen mahalle idi. Sulu Manastır'da yer alan mahallede gayrimüslim cemaatten Rumlar, Ermeniler ve Yahudiler birlikte yaşamaktadırlar. Gayrimüslimlerin oturduğu mahallelerden biri de Fener kapısı içerisinde yer alan ve "Abdi Subaşı Mahallesi" şeklinde kaydedilmiş mahalledir. El-hac İsa Mahallesi gayrimüslimlerin yoğun olarak yaşadıkları diğer bir mahalledir. Burada özellikle Yahudiler çoğunlukta olmak üzere diğer cemaatlere mensup kimseler de oturmaktadır. Altmış dört mahallede gayrimüslim

157 Numaralı sicilde geçmektedir.

157 Numaralı sicilde Yarhisar Musluhiddin olarak kaydedilmiştir.

93 Numaralı BabŞS sicilde kaydedilmiştir.

53 BabŞS 154- 11b/ 1 (H.12 B 1144/ M.10 Ocak 1732). 
halkın Müslüman halkla birlikte aynı mahallelerin belli kısımlarında yaşadıkları anlaşılmaktadır. Karışık mahallelerde nüfusun çoğunluğunu gayrimüslimler teşkil etmektedir. Gayrimüslimlerin müstakil olarak yaşadıkları mahalle sayısı ise altı olarak tespit edilmiştir. Zikredilen yerleşim yerlerinin dişında Müslümanlar sur içindeki mahallelerde nüfus bakımından çoğunluğu oluşturmaktadır ki Müslüman mahallelerin sayısı gayrimüslimlerinkine oranla oldukça fazladır.

İstanbul'un çeşitli mahallelerinde sayıları az olmakla beraber Kıptiler oturmaktaydı. Bunlar Aydın Kethüda, Ali Paşa, Beyazıt Ağa ve çoğunlukla da Manisalı Çelebi Mahallesinde yaşıyorlardı. XVIII. yüzyılın ilk yarısının sonlarına doğru Kıpti nüfusta bir artış meydana gelmiştir. Artışın nedeni Vize, Saray ve sair taraflardan Müslüman ve gayrimüslim Kıptilerin yerlerini terk ederek aileleriyle birlikte İstanbul'a çeşitli bahanelerle göç etmesiydi. Kimisi demircilik, rençperlik kimisi de serhatlı olduğunu söyleyerek cambazlık yapmak üzere geldiklerini ileri sürüyorlardı. Gelenler Topkapı-Edirnekapı arasında ve Tekfur Sarayı ile Ayvansaray etrafına yerleşmekteydi. Yine bir kısmı At Pazarı'na ve Fatih Camii civarında Karaman Çarşısı etrafina yerleşmişti. Bulundukları yerlerde Yahudihane tarzında odalar giderek artmaya başlamıştır. Ayrıca Kıptiler bulundukları yerlerde kendi halinde olmayarak asayişi bozan davranışlar sergiliyordu. Mahalle aralarında vatandaşların yollarını keserek ya da evlere gizlice girerek eşya ve paralarını çalıyorlardı. Belgelerde giderek hırsızlığı kendilerine meslek edinmeye başladıklarından bahsedilmektedir. Söz konusu olumsuz davranışlardan dolayı 1732 senesinde İstanbul kadısı ve Yeniçeri ağasına bir dizi buyruldular gönderilerek, bunlara karşı önlemler alınması istenmiştir. Buna göre ahalinin huzurunu bozan ne kadar Müslüman ve gayrimüslim Kıpti varsa tespit edilerek memleketlerine gönderilecekti. ${ }^{54} \mathrm{Bu}$ konuda tolerans gösterilmemesi özellikle vurgulanmaktayd.

\section{2. İstanbul'da Yeşil Alanlar}

\section{a. Bahçeler ve Bostanlar}

İstanbul, XVI. - XVIII. yüzyıllar boyunca dünyanın büyük şehrinden biri olma özelliğini korumuştur. Şehir nüfusunun büyük çoğunluğu yönetici, asker ve ilim

54 BabŞS 154-11b/ 2 (H.12 B 1144/ M.10 Ocak 1732). 
çevrelerinden ve çeşitli meslekleri icra eden halktan oluşmaktaydı. Bu sebeple şehirde demografik yapının tüketici yoğunluklu olduğunu söylemek mümkündür. Nüfus yoğunluğunun bu şekilde XIX. yüzyılda da devam ettiği görülmektedir. Bu sebeple kentin iaşesinin sağlanması önemli sorunlardan biri olmuştur. Kent halkının iaşesi kısmen şehir ve çevresindeki üreticilerden büyük bir kısmı ise dışarıdan karşılanıyordu. Özellikle sebze ve meyve gibi dayanıksız gıda maddelerini uzak bölgelerden zarar görmeden getirilmesi pek mümkün görünmüyordu. ${ }^{55}$ Sebze tedariki kentteki bahçe ve bostanlardan ve yakın çevrelerden elde ediliyordu. Meyve tedariki ise, yine kent çevresi ile daha geniş alanlardan sağlanıyordu. Ancak dışarıdan getirilen meyveler de Marmara sahil şeridinin ötesine geçmiyordu. İstanbul için taze sebze ve meyve tedarik alanları olarak kente hızlı taşıma yapılabilecek bölgelerin seçilmesinin nedeni bu ihtiyaç maddelerinin dayanıksızlığ 1 ile yakından ilgilidir. ${ }^{56}$

İstanbul ve çevresindeki bahçe ve bostanlar kalabalık nüfuslu büyük kentin ihtiyaçlarını karşılayacak şekilde örgütlenmişti. ${ }^{57} \mathrm{Bu}$ nedenle kent ve çevresindeki bahçe ve bostanlar sur içinin önemli bir parçasını teşkil ediyordu. Öyle ki İstanbul kenti baştanbaşa bahçe ve bostanlarla bezenmişti. Kentin her yerinde sular bol olduğundan bahçe ve bostanlarda her türlü meyve sebze yetişmekteydi. ${ }^{58}$ İstanbul'un bu özelliği semtlerin isimlerine bile yansımıştır. Bahçe ve bostan isimlerinin yanı sıra içinde yetiştirilen meyve sebzelerin isimlerini taşıyan çok sayıda mahalle ve semt vardı. Bazı semtler orada yetiştirilen sebze ve meyveleriyle ünlüydü. Tuzla bamyası, Yedikule marulu, Arnavutköy çileği, Çengelköy salatalık ve ayvasıyla, Kavak inciri ile meşhurdu. ${ }^{59}$

Bahçe, kelime anlamı itibariyle küçük bağ anlamına gelir. İçinde veya daha ziyade çevresinde bulunan, meyve ağaçlarının veya süs bitkilerinin yetiştirildiği, umumiyetle etrafı çevrilmiş bir yerdi. Vakfiyelerde söz konusu edilen bahçeler boyutları itibariyle birbirilerinden oldukça farklıydılar. Birisi ancak bir dönümlük bir yüzölçümüne sahip olduğu hâlde, bir başkasınınki yüz dönüm veya daha fazlaydı. Bu

55 Arif Bilgin, "Osmanlı Dönemi İstanbul Bostanları (Bir Giriş Denemesi1, Yemek ve Kültür, İlkbahar 2010, S. 20, s.86.

56 Bilgin, "Osmanlı Dönemi İstanbul Bostanları...," ss.86-87.

57 Bilgin, “Osmanlı Dönemi İstanbul Bostanları...”, s.87.

$58 \mathrm{Bu}$ kadar kal'anın içi toptolıdur. Halî yir yokdur meğer çayır ya bag̣çeler ola ya bostanlık ola. Böyle yirler de vardur. İncirlik, bostanlık çokdur. Her tarafınun suları firavan ne bitse olur. Seyahat-nâme, s.151a.

59 Beşir Ayvazoğlu, “İstanbul Kültürü ve Estetiği”, Şehir ve Kültür İstanbul, Ahmet Emre Bilgili (ed.), İstanbul, Profil yay, 2011, s.29. 
bahçelerden bazıları sadece tek cins ağaçlar ihtiva ediyorlar ve adlarını bu ağaçlardan alıyorlardı. Dut bahçesi olarak kayda geçirildiği gibi bazıları eşcar-ı müsmire ve gayr-ı müsmir (meyve ağaçları ve meyvesiz ağaçların olduğu) bahçe şeklinde kaydedilmiştir. $\mathrm{Bu}$ bahçelerin yanında, hemen hemen bahçelerle aynı genişliğe sahip, sebze ekimine ayılmış nadiren ağaçlar, fakat özellikle bostancının oturması için küçük bir ev, ahırlar, sundurmalar, su kuyuları, havuzlar ve sudolapları bulunan bostan'lar uzanıyordu. ${ }^{60}$ Bostanlar sadece sebze üretiminin yapıldı̆̆ı yerler değildir. Şehir ve çevresindeki pek çok bostanda meyve ağaçları bulunuyordu. ${ }^{61}$ Hatta bazı bostanlarda sadece meyve ağaçları vardı. Bu tür bostanlar yemiş bostanı olarak anılmaktaydı. ${ }^{62}$

XVIII. yüzyılın ilk yarısında İstanbul sur içinde kaç tane bahçe ve bostan vardı? Kimler çalışıyordu? Bunlara dair verileri kadı sicillerine kaydedilmiş olan kefil defterlerinden tespit etmekteyiz. Evlere ait olan küçük bahçelere ilişkin verilere yine sicillerde yer alan mülk alışverişine konu olan davalardan ulaşmaktayız. Taramalar sonucunda iki adet kefil defterine rastlanılmıştır. ${ }^{63}$ Kefil defterinden ilki Kasım 1719 tarihli olandır. Bu defterde İstanbul ve çevresinde bulunan bostanların, bostancıların ve çalışan hizmetlilerin isimlerinin tutulduğu görülüyor. Deftere göre 195 bostan tespit edilmiştir. Bostanlar Langa'dan Yedi Kale ve Yeni bahçeye kadar olan kısımda sıralanmıştır. İkinci defter 1731 tarihlidir. Bu defterde İstanbul'daki büyük küçük bostanların sayısı 126 bahçelerin sayısı ise 30'dur. Bahçe ve bostanlar üç kol halinde

60 Bahaeddin Yediyıldız, "XVIII. Asır Türk Vakıflarının İktisâdî Boyutu”, Vakıflar Dergisi, C. XVIII, Ankara 1984, s.7.

61 Keşif için Bostancıbaşı kethüdası ve yiğit başılar bir bostana giderek bostanda bulunan meyve ağaçlarının sayısını ve türlerini kaydetmiştir. Buna göre bahçede 9 incir, 18 erik, 7 armut, 2 beyaz dut, 8 kayısı, 15 ayva, 5 şeftali, 2 adet elma ağaçları vardır. BabŞS 156-102a/3 (H. Gurre-i B 1145/ M. 1822 Aralık 1732).

62 Bilgin, “Osmanlı Dönemi İstanbul Bostanları", s. 86.

63 Kefil defterleri, bahçe ve bostanlarda kimlerin çalıştığını tespit ederek kefili olmayanların çalıştırılmaması amacıyla tutuluyordu. Böylece iş gücü fazlası tespit edilerek kefili olmayan kişiler kent dışına çıkarılıyorlardı. Bu şekilde İstanbul ve çevresinin asayişi sağlanmaya çalışılıyordu. Kefil defterinden ilki Kasım 1719 tarihli olandır. Bu defterde İstanbul ve çevresinde bulunan bostanların, bostancıların ve çalışan hizmetlilerin isimlerinin tutulduğu görülüyor. Deftere göre 195 bostan tespit edilmiştir. Bostanlar Langa'dan Yedi Kale ve Yeni bahçeye kadar olan kısımda sıralanmıştır. BabŞS 123- 26-27 a-b/ 1 ( H.14 M 1132/ M.27 Kasım 1719). Defterin başına düşülen ibare aynen şöyledir: İstanbul ve Eyüp el'Ensari ve Galata ve Üsküdar dâhilinde ve haricinde ve tevabi'inde olan bostanların müstacerlerin ve yanaşmaların ve iş hizmetkârlarının ve ortakların cümlesinin kefilin beyan eder. Kaç kol olduğun beyan eder. Fi Muharrem 1132”. İkinci kefil defteri ise Sur içine ait Kasım 1731 tarihlidir. Bu defter diğerine göre daha ayrıntılı kaydedilmiştir. Defterde sadece bostanların değil bahçelerin isimlerinin de zikredildiği görülmektedir. Bahçelerin sahipleri ve kiracı olarak kimin tasarruf ettiği verilen bilgiler arasındadır. BabŞS 153- 3-13 a-b/ 1 (H.28 Ca 1144/ M. 28 Kasim 1731). 
(Büyük Langa, Yedi Kale, Küçük Langa) uzanmaktadır. Bahçe ve bostanların 59’u Büyük Langa'da, 84'ü Yedi Kule ve çevresinde, 13'ü ise Küçük Langa ve civar mahallerdedir. Çalışan hizmetlilerin sayısı 640 olarak tespit edilmiştir. Bahçe ve bostan sahipleri buraları işletmek üzere başkalarına kiralardı. Kiracı konumundaki bostancılar ve yanlarında çalışan işçilerin büyük çoğunluğu Hıristiyan Bulgar ve Rumlardır. Bulgarların Makedonya'nın Vodina, Ohri, Pirlepe, Üsküp, Manastır, Ostrova, Florina ve Tikveş’ten geldiğini görüyoruz. Yine Yunanistan'dan Niş ve Selanik şehirlerinden gelenler vardır. Bir kısmının ise Sofya'dan geldiği tespit edilmiştir. Rum kökenli işçilerin bir kısmı İstanbullu Rum, diğer büyük bir kısmı ise Niğdelidir. Bunların dışında özellikle bahçe işinde çalışan işçiler arasında Arnavut kökenliler vardır. Arnavutlar bahçıvanlık mesleğinde iyi olduklarından Permeti ve İspiç halkı bahçe işlerinde çalışmak üzere İstanbul'a sıklıkla gelip gidiyordu. İspiç halkı bu sebepten Türkçe de konuşurdu. ${ }^{64}$

Bahçe ve bostanların işletmesi bostancı ustaları tarafından gerçekleştirildi. Ustalar Müslüman ve gayrimüslim olabilirdi. Büyük bir çoğunluğunun ise gayrimüslimlerin oluşturduğu görülüyor ${ }^{65}$. Çalışan hizmetli işçiler de genellikle usta nereli ise onlar da onun memleketlisiydi. Çünkü her usta kendisine işçi alırken onlara kefil olmakla sorumluydu. Aksi takdirde onların yapacakları olumsuz fiillerden kendileri sorumlu olacaktı. Bundan dolayıdır ki tanıdıkları kişileri ya da bostancıların kefil oldukları kimseleri işe almayı tercih ettikleri söylenebilir. Çalışmak isteyenlerin temessük adındaki belgeyi alması gerekmekte idi. Temessük çalışma izni olan kişilere veriliyordu. Temessükün düzenlenmesinden maksat çalışma izni ve kefili olmayan kişilerin işlerine son vermekti. ${ }^{66}$ Bir diğer sebep ise kontrolsüz iş gücü fazlalığının önüne geçmekti. Çünkü yukarıda bahsi geçtiği üzere bu tarihlerde taşradan,

${ }^{64}$ Cevdet Paşa Tezakir isimli eserinde bu konuyu izah etmiştir: Bar kazası ahalisi Boşnak olup Boşnakça konuşurlar.. Fakat İspiçliler ekseriya Bahçıvalık için İstanbul'a gelip gittiklerinden Türkçe de konuşurlar. Bar kazasında da hem Boşnakça hem de Türkçe konuşulmaktadır. Mirkut nahiyesi ise Ülkün ve bir taraftan İşkodra kazalarına yakın olduğundan buralar halkı Arnavutçayı biliyordu. İspiç bayraklarının hanesi Zangut Mahallesindedir. Ve Zangut ismi aslen bayrakdar ailesinden gelmekteydi. Cevdet Paşa, Tezâkir, II. Seri, TTK, Ankara 1960, s.190; İlkay Erken, İşkodra Vilayetinin İdari ve Sosyal Yapısl, Basılmamış Yüksek Lisans Tezi, Samsun 2014, ss.36-37.

65 BabŞS 153-3-13a-b/1 (H. 28 Ca 1144/M. 28 Kasım 1731); Bilgin, "Osmanlı Dönemi İstanbul Bostanlar1", s. 90.

66 Mesela, 1730 'da baş gösteren Patrona isyanından sonra kefilsiz ve temessüksüz olan bostan oğlanlarının memleketlerine gönderilmesi için bir ferman çıkartılmıştı. $\mathrm{Bu}$ fermana yapılan yoklamanın öncekilere göre daha keskin olduğu anlaşılmaktadır. Böyle bir uygulamaya gidilmesinde İsyanda rol oynayanların büyük bir kısmının Arnavut kökenli olması etkili olmuştur. Kaldı ki özellikle sur dışında ve sur içinde bahçe ve bostanlarda çalışan Arnavut işçi sayısı az değildi. Bilgin, "Osmanlı Dönemi İstanbul Bostanları", s. 90. 
Makedonya'dan çalışmak üzere mevsimlik işçiler geliyordu. Böyle zamanlarda kalabalık nüfuslu kent asayişinin temininde sıkıntılar baş gösterebiliyordu. İşte kefillik sistemi ve temessük belgesi sayesinde işçi sayısı kontrol altında tutularak kentin asayişi sağlanmaya çalışılıyordu.

Bulgar kökenli gayrimüslimlerin istihdamına 1728 'de çıkarılan bir fermanla son verilmeye çalışılmıştır. ${ }^{67}$ Ancak 1731 tarihli kefil defterinde bahçe ve bostanları işleten ve çalışanlar arasında Bulgar kökenlilerin olduğu tespit edilmiştir. Dolayısıyla yasaklamalara rağmen ya suiistimaller görülmüş olmalıdır ki tamamen önü alınamamıştır. Ya da bu konuda katî uygulamalardan uzak durularak çalışmalarına göz yumulduğu söylenebilir.

Bir bahçe ve bostanda bir ila sekiz kişi arasında insan çalışıyordu. Çalışan işçi sayısının fazla olduğu bostanların diğerlerine göre daha büyük oldukları söylenebilir. Mesela Büyük Langa civarındaki Yeni Bostan'da yer alan Baş Oda Bostan'ı bunlardan biridir. Bostanı işleten Yovan İstanbullu olup Rum'dur. Bostanda altı işçi çalışmaktadır. Yedikule yakınlarındaki İsmail Paşa Sarayı Bostanı'nda bostancılar Anastas ve ortağı Petro'dur. Bostan büyük olduğundan çalışan işçi sayısı sekizdir.

Bahçe ve bostanları kiracı olarak işletenler tek kişi olabileceği gibi ortak olarak birden fazla kişi de olabilmekteydi. Kumkapı'da Tavaşlı Süleyman Ağa Mahallesi’nde bulunan Bezazistanî es-Seyid Süleyman Ağa Bahçesini işleten İstanbullu Ermeni usta Avak’tır. Bahçenin işlerini yürütmek üzere iki işçi görevlendirilmiştir. Başka bir örnekte bahçenin ortaklaşa işletildiği görülüyor. Kumkapı'daki İbrahim Paşa Mahallesi'nde Osman Kethüda'nın evinin karşısındaki bahçeyi işletenler üç kişidir. Dimitri ve ortakları Bıyıklı Manok ve kardeşi Nikola'dır. Bu kişilerin Bulgar oldukları anlaşılıyor. Bahçede bir hizmetçi görevli olup o da Vardar Yenicesi’nden Bulgar Dimo'dur.

İstanbul'un sebze ve meyve ihtiyacını karşılayan bahçeler yanında başka işlevlere yönelik hizmet veren büyük bahçeler vardı. Halkın vakit geçirmesi ve eğlenmesi amacıyla asıl kent ve kent sınırları dışındaki sahalarda da bahçeler, mesire alanları oluşturulmuştu. Zaten Osmanlı İstanbul'unda güzel bahçe sahibi olmak hatta büyük boyutlu bahçeleri kamusal alan olarak halka bahçe yapıp vakfetmek geleneği

67 Bilgin, “Osmanlı Dönemi İstanbul Bostanları”, s.92. Ferman için bkz. ÜŞS no.378. 
vardı. $\mathrm{Bu}$ işin öncülüğünü başta saray yapmıştır. Topkapı Bahçesi, Yıldız Bahçesi, Kandilli Bahçesi gibi Padişahların has bahçeleri, vezirler ve diğer devlet ileri gelenleri tarafından taklit edilerek şehrin başka yerlerinde yaygınlaştırılmıştır. Haliç kıyılarında Karaağaç Bahçeleri, Hasköy Bahçeleri vardı. Boğaziçi kıyılarında Kabataş’ta Karabali Bahçesi, Beşiktaş’ta Kazancıoğlu Bahçesi, Emirgan'da Emirgan Bahçesi gibi bahçeler İstanbul'un tarihi bahçeleriydi.

Asıl kent sınırları içinde bu geleneğe uygun olarak bahçe yapımına önem verilmişti. Bunun neticesinde olsa gerek kentte yer alan büyük bahçelerden birçoğunun umumiyetle büyük devlet adamlarına ait olduğu gözlenmektedir. Çünkü bu bahçeler devlet adamlarının isim ve unvanlarıyla adlandırılmıştır: "Eski Beğlikçi Bahçesi”, “İstanbul Kadısı Paşazade Efendi Bahçesi”, "Ebubekir Paşa Bahçesi”. Ya da bahçe sahiplerinin mesleklerinin isimleri verilmiştir: "Gümrükçü Hüseyin Paşazade Bahçesi”, "Dibacı Hacı İsmail Bahçesi". 68

Büyük hasbahçeler, bahçe-bostanlar yanında her evin de değişik büyüklükte bahçesi vardı. Güzellik ve faydayı birlikte düşünerek yerleştikleri yerlerde bu ikisini sentezleyen Osmanlılar içinde meyve ağaçları ve çiçek olmayan bahçeyi bahçeden saymazlard1. ${ }^{69} \mathrm{Bu}$ durum diğer Müslüman Türk şehirlerinde olduğu gibi İstanbul için de geçerliydi. Çünkü Türkler bina yaptığı araziyi ilk önce duvarla örüp ağaç dikerdi. XVIII. yüzyılda evlerin bahçe şehir olma özelliğini koruduğu kaynaklardaki bilgilerden anlaşılmaktadır. Sicil kayıtlarındaki ev alış veriş belgelerinde sıklıkla meyveli ve meyvesiz ağaçlardan oluşan bahçelere atıflar yapılmıştır. Bahçesinde dut, ayva ya da başka meyveli ve meyvesiz ağaçları bulunan pek çok ev vardı. Bunun yanı sıra bahçeler ve çiçekler devrin şairlerinin şiirlerinde de bir öğesi olmuştur. Sibyan mekteplerinde okuyan çocuklar sabahları bir çiçek demeti hazırlayarak hocalarına götürürlerdi. Mahallede eğer bir hasta varsa çocukların sessiz olması için pencerelerin önlerine hasta olduğu anlamına gelen çiçekler yerleştirilirdi. Yine hasta ziyaretine gidilirken gül, lale götürülerek hal hatır sorulurdu. ${ }^{70}$ Eski İstanbul'da sarayların ve büyük konakların bahçelerinin olmazsa olmaz çiçekleri lale ve güllerdir. ${ }^{71}$ XVIII. yüzyılda lale

68 BabŞS 153- 3-13 a-b/ 1 (H.28 Ca 1144/ M. 28 Kasım 1731).

69 Beşir Ayvazoğlu, “Ağaçlar ve Bahçeler”, Şehir ve Kültür İstanbul, s.31.

70 Beşir Ayvazoğlu, “Ağaçlar ve Bahçeler”, Şehir ve Kültür İstanbul, s.33.

71 "Bugün yolum bir gül bahçesine uğradı ama hayretten aklım başımdan gitti. Ne görsem beğenirsin: Dünya baştanbaşa bezenmiş... kırları tepeleri, sağı solu baştanbaşa gül, sünbül ve lâle bahçeşeri..." Nedim Divânı'ndan Seçmeler, Şevket Kutkan (çev.), İstanbul; Kültür Bakanlığı Yay, 1981, s.222223. 
yetiştiriciliği oldukça ciddi boyutlara ulaşmıştır. Hatta lalelere narh uygulanarak ciddi bir piyasası oluşmuştur. ${ }^{72}$ Evlerin bahçelerinde laleden başka kokulu ve çiçekli çeşitli çiçekler tercih edilirdi. Sıradan fukara bir evin bile pencerelerinde sardunya ve fesleğen saksıları olmazsa olmazlardand1.

Cami avluları dinî ibadetlerin yapıldığı yerler olmasının yanında halkın toplanıp dinlendikleri yerlerdi. Bu cami ve mescit önlerindeki alanlarda değişik türden ağaçlar yükselmekte ve İstanbul'un manzarasının önemli bir parçasını oluşturmaktaydı. Ağaçlar sadece estetik güzellik ve serinlik kaynağı değildi. Her biri çevresinde yaşayanlar için bir anlam taşırdı. Öyle ki bu ağaçlar altında padişah ve yönetimin dedikoduları yapılır, hararetli tartışmalar yaşanırdı. Mahallede olup biten yine bu ağaçlar gölgesinde konuşulur yazın ise eğlenceler tertip edilir oyunlar düzenlenirdi. Mezarlıkların simgesi olan servi ağaçları ise ebedi bir dinlenmenin sembolleriydi. Evlerin bahçelerinde bulunup sokağa ya da karşı komşunun çatısına uzanan ağaçlar ise bazı durumlarda komşular arasında anlaşmazlık yaratarak husumetlerin yaşanmasına bile neden olabiliyordu.

Tablo. 2 İstanbul Sur içindeki Bahçelerin İsimlerini Gösteren Liste ${ }^{73}$

\begin{tabular}{|c|c|c|c|c|}
\hline & Bahçe İsmi & $\begin{array}{c}\text { Bahçenin Bulunduğu } \\
\text { Yer }\end{array}$ & $\begin{array}{l}\text { Kiracının ismi ve } \\
\text { Geldiği Yer }\end{array}$ & $\begin{array}{c}\text { Çalışan } \\
\text { Hizmetl } \\
\text { Sayısı }\end{array}$ \\
\hline 1 & Eski Beğlikçi Bahçesi & $\begin{array}{l}\text { Kumkapı'da Nişancı } \\
\text { Paşa Mahallesi }\end{array}$ & $\begin{array}{l}\text { Kino, Permeti'den } \\
\text { Arnavut }\end{array}$ & 4 \\
\hline 2 & Ebubekir Paşa Bahçesi & $\begin{array}{l}\text { Kumkapı'da Nişancı } \\
\text { Paşa Mahallesi }\end{array}$ & $\begin{array}{l}\text { Asvador, İstanbullu } \\
\text { Ermeni }\end{array}$ & 2 \\
\hline 3 & $\begin{array}{l}\text { Bezastanî es-Seyid Süleyman } \\
\text { Ağa }\end{array}$ & $\begin{array}{l}\text { Kumkapı'da Tavaşlı } \\
\text { Süleyman Ağa Mah. }\end{array}$ & $\begin{array}{l}\text { Ağya? İstanbullu } \\
\text { Ermeni }\end{array}$ & 2 \\
\hline 4 & $\begin{array}{l}\text { Saraç Hacı Abdullah'ın evi } \\
\text { önündeki küçük Bahçe }\end{array}$ & Aksray’da Kızıl Maslak & Hacı Abdullah & 1 \\
\hline 5 & $\begin{array}{l}\text { Kasapoğlu Hacı İbrahim } \\
\text { Bahçesi }\end{array}$ & Çakır Ağa Mahallesi & $\begin{array}{l}\text { Bagaso?, Rum ve } \\
\text { İstanbullu }\end{array}$ & 4 \\
\hline 6 & Ebubekir Paşa Bahçesi & Aksaray & Lazalko?, Permetili & 2 \\
\hline 7 & $\begin{array}{l}\text { Eski İstanbul Kadısı Paşazade } \\
\text { Efendi Bahçesi }\end{array}$ & Aksaray & $\begin{array}{l}\text { Kosta, Permetili } \\
\text { Arnavut }\end{array}$ & 2 \\
\hline 8 & Firarî Hasan Paşa Bahçesi & $\begin{array}{l}\text { Büyük Lanka Kolunda } \\
\text { İsmail Ağa Mahallesi }\end{array}$ & $\begin{array}{l}\text { Mehmet, İstanbullu } \\
\text { ve biladerlik }\end{array}$ & 2 \\
\hline 9 & $\begin{array}{l}\text { Hocazade es-seyid Abdullah } \\
\text { Bahçesi }\end{array}$ & Büyük Lanka & $\begin{array}{l}\text { Yano, Permetili } \\
\text { Arnavut }\end{array}$ & 2 \\
\hline
\end{tabular}

72 Mantran, Istanbul Tarihi, s.270.

${ }^{73}$ BabŞS 153-3a-13b (H. 28 Ca 1144/M. 28 Kasım 1731). 


\begin{tabular}{|c|c|c|c|c|}
\hline 10 & $\begin{array}{l}\text { Gümrükçü Hüseyin Paşazade } \\
\text { Bahçesi }\end{array}$ & Büyük Lanka & $\begin{array}{l}\text { Rasto, Permetili } \\
\text { Arnavut }\end{array}$ & 2 \\
\hline 11 & Dibacı Hacı İsmail Bahçesi & Yedi Kule'de Bucakbağ 1 & $\begin{array}{l}\text { Hac1 İsmail kendi } \\
\text { ustadır }\end{array}$ & 4 \\
\hline 12 & $\begin{array}{l}\text { Yedi Kule Ağası merhum } \\
\text { Osman Ağa Bahçesi }\end{array}$ & Yedi Kule & $\begin{array}{l}\text { Todori, Niğdeli ve } \\
\text { Rum }\end{array}$ & 1 \\
\hline 13 & $\begin{array}{l}\text { Merhum Tuğcu Mustafa Çavuş } \\
\text { bahçesi }\end{array}$ & Yedi Kule & Mehmet & 1 \\
\hline 14 & Hacı Abdullah Bahçesi & $\begin{array}{l}\text { Yedi Kule'de Hâce } \\
\text { Kadın civarında }\end{array}$ & $\begin{array}{l}\text { Yorgi, Yanyalı ve } \\
\text { Rum }\end{array}$ & 1 \\
\hline 15 & Kaburizade? Bahçesi & $\begin{array}{l}\text { Yedi Kule'de Davut } \\
\text { Paşa'daki Kolluk } \\
\text { civarında }\end{array}$ & $\begin{array}{l}\text { Niko, Permetili ve } \\
\text { Arnavut }\end{array}$ & 2 \\
\hline 16 & Davut Paşa Camii Bahçesi & $\begin{array}{l}\text { Yedi Kule'de Davut } \\
\text { Paşa Camii }\end{array}$ & $\begin{array}{l}\text {....? Permetili ve } \\
\text { Arnavut }\end{array}$ & 1 \\
\hline 17 & Mustafa Ağa Bahçesi & $\begin{array}{l}\text { Yedi Kule Odabaşı } \\
\text { sevkinde }\end{array}$ & $\begin{array}{l}\text { Kiko (Kirko)? } \\
\text { Arnavut }\end{array}$ & - \\
\hline 18 & Mevlevi Hacı Mustafa Bahçesi & $\begin{array}{l}\text { Yedikule'de Odabaş1 } \\
\text { sevkinde }\end{array}$ & $\begin{array}{l}\text { Kilo Permetili } \\
\text { Arnavut }\end{array}$ & 1 \\
\hline 19 & Hüseyin Ağa Bahçesi & $\begin{array}{l}\text { Yedi Kule'de Mimar } \\
\text { civarında }\end{array}$ & $\begin{array}{l}\text { Minho, Ostrovalı ve } \\
\text { Bulgar }\end{array}$ & 2 \\
\hline 20 & Mehmet Efendi Bahçesi & $\begin{array}{l}\text { Yedi Kule'de Abacı } \\
\text { Bayezıt Mahallesi }\end{array}$ & $\begin{array}{l}\text {...? Permetili ve } \\
\text { Arnavut }\end{array}$ & - \\
\hline 21 & Şeyh Hasan Efendi Bahçesi & $\begin{array}{l}\text { Yedi Kule İbrahim Paşa } \\
\text { Camii }\end{array}$ & Astavri Bulgar & 1 \\
\hline 22 & Ali Bahçesi & $\begin{array}{l}\text { Yedi Kule İbrahim Paşa } \\
\text { Camii }\end{array}$ & $\begin{array}{l}\text { Mihayil, İstanbullu ve } \\
\text { Rum }\end{array}$ & - \\
\hline 23 & Kefe Halifesi Bahçesi & $\begin{array}{l}\text { Yedi Kule'de Silivri } \\
\text { Kap1 }\end{array}$ & $\begin{array}{l}\text { Manok, İstanbullu ve } \\
\text { Ermeni }\end{array}$ & 1 \\
\hline 24 & Süleyman Ağa Bahçesi & Yedi Kule'de Akarca & $\begin{array}{l}\text { Miço, Avlonyalı ve } \\
\text { Arnavut }\end{array}$ & 1 \\
\hline 25 & Yorganî el-Hac Yahya Bahçesi & $\begin{array}{l}\text { Yedi Kule'de Meşeli } \\
\text { Mescit'te }\end{array}$ & Yovan, Bulgar & 3 \\
\hline 26 & Tophane Şeyhi Bahçesi & $\begin{array}{l}\text { Yedi Kule'de Ağa } \\
\text { Çayırında }\end{array}$ & $\begin{array}{l}\text { Avlendo, Niğdeli ve } \\
\text { Rum }\end{array}$ & 2 \\
\hline 27 & Usta Minas Bahçesi & $\begin{array}{l}\text { Yedi Kule'de Ağa } \\
\text { Çayırında }\end{array}$ & $\begin{array}{l}\text { İvannes İstanbullu ve } \\
\text { Ermeni }\end{array}$ & - \\
\hline 28 & Küçük Kadın Bahçesi & $\begin{array}{l}\text { Küçük Lanka'da Davut } \\
\text { Paşa İskelesi civarında }\end{array}$ & $\begin{array}{l}\text { Marko, Ohrili ve } \\
\text { Bulgar }\end{array}$ & 1 \\
\hline
\end{tabular}

\section{b. Mesire Yerleri}

Osmanlı ilk devirlerinde yeşil alanlar diğer dünya kentlerine göre farklı bir biçimde konumlandırılmıştır. Yeşil alanlar kamu kullanımına açık büyük yeşil alanlar olarak değil özel mülkiyete konu olan küçük bahçeler ya da cami avlularındaki yeşil alanlar olarak kente dağılıyordu. Bu durum XVI. yüzyıldan itibaren değişmeye başlamıştır. Mesire yerlerinin kamu alanı olarak halka açılması ve asıl önemini kazanması XVIII. yüzyıldan itibaren olmuş ve dönüşüm XIX. yüzyılda devam etmiştir. Bu dönemlerde 
kent genelinde çayırlıklardan oluşan mesire alanları oluşturulmuştur. Bundan sonraki tarihler bu manada İstanbul'daki her semtin kendi mesire alanına kavuştuğu dönemdir. İstanbul halkının vakit geçirmesi ve eğlenmesi amacıyla sur içinde ve dışında çok sayıda gezinti yerleri, mesire alanları, bahçeler ve çayırlar vardı. Silivrikapı'daki Ağa Çayırı, Topkapı'da Yeni Bahçe, Vefa, büyük camilerin meydanları, Yedikule, Büyük ve Küçük Langa Bağları, Yenikapı, Alibeyköy ve Lâlezar Mesireleri bunların önde gelenleriydi. Ayrıca sur dışı alanlarda Topkapı ve Edirnekapı dışında Topçular, Otakçılar çayırları ve Eyüp vardı. ${ }^{74}$ İstanbul halkı gezmek için çoğunlukla Eyüp’e uğramaktayd1. İstanbul'da Eyüp'ten sonra en çok ziyaret edilen mesire yeri Kâğıthane'dir ve Eyüp'e bir iki saat uzaklıkta mesafededir. ${ }^{75}$ Lâlezar Mesiresi de buradaydı ve Kâğıthane Lalesi denilen rengârenk laleler yetişirdi. Önemli bir yere sahip İmrahor Köşkü, Kâğıthane nehri kenarındaki çayırda yer alan ahşap bir kasırdı. Bunlardan başka burada, XVI. yüzyılda Kanunî Sultan Süleyman'ın yaptırdığı su kemerleri vardı. Kanunî devrinde, İstanbul halkı kayıklara binerek İstinye'ye giderek Yeniköy’de gezinirdi. Burası padişahın emriyle inşa edilmişti.

İkinci Selim zamanında Boğaziçi kıyılarında ünlü bahçelerden biri Beşiktaş olmuştur. Kaptan Sinan Paşa ile Barbaros Hayrettin Paşa'nın türbe ve camileri burada çınarları ve beyaz kurşunlu kubbeleriyle güzel bir manzara teşkil ediyordu. Beşiktaş’ta diğer ünlü bir yer Yahya Efendi Mesiresi idi. Buradan itibaren Galata'ya kadar Fındıklı ve Tophane camiler ve saraylar ile doluydu. Camilerin arka tarafları ise tamamen ağaçlıktı. Boğaz, Fındıklı'dan itibaren ormanla çevrili bir yerdi. Boğazın sularını çevreleyen korular ve çayırlara kent halkı gitmekten haz alıyordu ${ }^{76}$

Kâğıthane, kentin fethinden itibaren her dönemde önemini korumuştur. Kâğıthane deresi etrafındaki büyük çınarlar, çayırlar İstanbul halkını ilkbaharda buraya çekerdi. Burası sulu olduğundan çayır ve çimenleri oldukça boldu. Padişah ve vezir atları bu çayırlarda otlardı. ${ }^{77}$ Özellikle halk arasında buraya Kırkçeşme'den getirilen

\footnotetext{
74 Mantran, XVI. Ve XVII. Yüzyllda İstanbul'da Gündelik Hayat, İstanbul; Eren Yay, 1991, s.216; Ahmet Refik, Eski İstanbul, Sami Önal (yay. haz.), İstanbul; İletişim, 1998, s.24.

75 “...Ekser İslambol'un halkı teferrüce buraya gelürler ve Kâğıdhâne bundan öte bir veya iki saat yirdür.” Resmî Kayseri, Seyahat-nâme, s.157a.

76 Altınay, Eski Istanbul, ss.25-26.

77 Resmî Kayseri, Seyahat-nâme, s.157a.
} 
sular rağbet görüyordu. Sonraları İstanbulluların sulardan, çayırlardan ve gölgeliklerden yararlanabilmesi için, çayırlarda hayvan otlatılması ve ağıllar yapılması yasaklanmıştı. ${ }^{78}$

İstanbul'un seçkin mesire yerleri arasında yer alan Kâğıthane'nin önem ve ününün artması III. Ahmed zamanında olmuştur. Özellikle Nevşehirli İbrahim Paşa'nın sadrazamlığında elçilere Kâğıthane'de ziyafetler verilmeye başlandı. Kâğıthane ve çevresindeki köylerin manzarası III. Ahmed'in sevdiği yerlerdi. Bu nedenle buralarda yeni alanlar oluşturuldu.

Alibeyköy'de üç tane havuz yapıldı. Burasının havası, suyu güzel ve yazın gölgelik veren ağaçlardan dolayı serin olduğundan halkın gitmekten hoşlandığı bir yer oldu. Burası Râşid tarafından Hüsrevâbâd olarak adlandırmıştı. Padişahın da bu ismi beğenmesi üzerine fermanla bundan sonra Hüsrebâbâd olarak anılmasını istemiş bir de buraya yazlık yapılmıştır. ${ }^{79}$ Daha sonra İbrahim Paşa Kâğıthane'de de bir saray yapmak istemiştir. Bunun üzerine büyük bir yapının inşasına başlanmıştır. Kasır ve havuzlar yapılmıştır. Bu tarihten itibaren Kâğıthane daha da canlanmış ve kent halkının akın ettiği gezinti yeri olmuştur. ${ }^{80}$ Özellikle ilkbahar mevsiminde Kâğıthane önemli bir eğlenme ve dinlenme alanı olmaktaydı. Burada güreşler düzenlenir, cambaz, hokkabaz ve kukla gösterileri yapılırdı. Bütün bu gösteriler ise buraya ayrı bir hava kattığından halk arasında oldukça revaç bulmuştu. İstanbul'da ne kadar ince, nâzende kadın varsa buraya eğlenmeye geliyordu. ${ }^{81}$

Sa'dâbâd saray ve çeşmelerinin yapımı Haliç kıyılarının imara açılmasını ve yeni binaların yapılmasını sağladı. Eyüp ve Bahariye gibi semtlerde çok sayıda büyük yalılar ve köşkler yapıldı. Buraların kıymeti artınca bu güzergâh kentin zenginlerinin oturduğu yerler oldu.

Asya kıyısında Çamlıca Tepesi Üsküdar'a hâkimdir. Bu tepede İstanbul ve çevresinin en ünlü su kaynağı bulunmaktadır. Boğaz’ın Asya kıyılarında kentin ileri gelenlerinin yalıları bulunuyordu. Bu yazlık evlerin etrafı bahçeler ve meyve ağaçları ile çevriliydi. Anadolu Hisarı yakınlarındaki Göksu deresi kıyılarındaki mesire yerleri ilgi görüyordu. İstanbullular burada sandal ve kayıklarla geziniyordu. Boğaziçi'nde yapılan

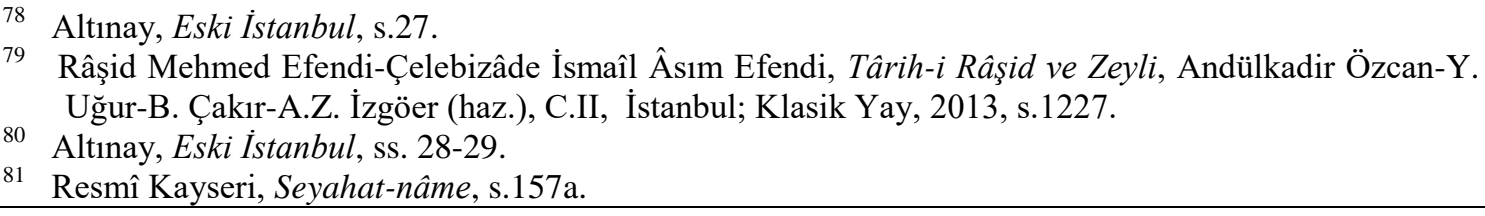


binaların sayısı çok fazla olmakla birlikte evlerin mimarisi doğayla uyum sağladığından bütünlük sağlamaktaydı. ${ }^{82}$

\section{c. Çarşı ve Pazarlar}

İstanbul'un siluetini oluşturan önemli yapılaşmalardan biri de çarşı pazarlardır. Kentin hangi tarafina gidilse dört bir köşesinde her şeyin mevcut olduğu uzmanlaşmış satış yerleri vardır. ${ }^{83} \mathrm{Bu}$ satış yerleri çarşı ve pazar adlarıyla anılmaktaydı. Bunlardan en önemlisi İstanbul'un fethinden sonra kente ilk eklemlenen yapılardan biri olan Kapalıçarşı'dır. Kentte ekonomik hareket ticaret yoluyla oluştuğundan Kapalıçarşı İstanbul'un kalbi sayılmıştır. Kapalıçarşı'nın çevresinde Büyük Bedesten ve Kürkçüler Hanı adlı çarşılar vardı. Geniş bir alana kurulmuş olan bu yapıda irili ufaklı 4000 adet dükkân bulunmaktadır. Kemerli bölmelerle her yöne çıkabilen sokaklarıyla adeta duvarla çevrili bir şehir gibidir. Her sokağın iki tarafına dükkânlar sıralanmış olan bu çarşının üzeri kapalı olduğundan yağmur, sıcak ve yangına karşı korunaklıdır. Güvenilirliği bu şekilde sağlandığından mücevher, ipek halılar gibi daha birçok değerli eşyanın alınıp satıldığı alan olmuştur. Ayrıca her yöne çıkabilen sokaklarıyla adeta duvarla çevrili bir şehir gibidir. ${ }^{84}$ İstanbul'un çarşıları ve Bedesten'deki dükkânlar ve kemerler kentte çıkan büyük yangınlar nedeniyle zarar gördüğünden yine aynı zararı görmemesi adına II. Mustafa zamanında kâgir hale dönüştürülmüştür. II. Mustafa buraların kâgir yapılmasını emredince esnaf bu konuda zorlanmıştır. Buna göre gücü yetenler dükkânları yeniden kâgir inşa ederken maddi gücü olmayanlar dükkânlarını satmak zorunda kalmıştır. Daha sonra dükkânların kubbe ve kemerleri kireçle sıvanarak üzerine nakışlar işlenmiştir. ${ }^{85}$

Bedesten çarşısındaki bazı dükkânlar kadınların hemen her gün uğrak yeridir. Çünkü bu çarşıdaki dükkânlarda kadın giysisi adına ne varsa satılıyordu. Bürümcük

82 Altınay, Eski İstanbul, s.30; Mantran, XVI. Ve XVII. Yüzyılda İstanbul'da ..., s.218.

83 “...her kangı tarafına gitsen çarşu bazardır. Bir mahalle yokdur ki anda çarşu mükemmel olmaya"Yani fülân diyârda fülân şey ucuzdur mahallinde, bir dânesini İ́slâmbol'a getürürsen bu kadar fâ'ide ider, diseler sakın'amel eyleme. Ol metâ' her ne ise ucuzdur alursun İslâmbol'a getürürsün bir yerde râst gelürsün ki iyüdür. Bir yerde yine ol metâ'a râst gelürsün ki yarı bahâsına satılur. Satmak murâd edersen zarar edersin, hâli böyledür".

84 Öztürk Emiroğlu, "Polonyalı İki Gezginin Kaleminden XIX. Yüzyıl İstanbul'u”, 7. Uluslararası Türk Kültürü Kongresi, Bildiriler II, s.103.

85 Resmî Kayseri, Seyahat-nâme, s.157a. 
gömlekler, donlar, çatkılar, entari ve kaftanlar ve daha birçok şey. ${ }^{86}$ Bedesten, aynı zamanda her türlü eşyanın açık artırma yoluyla satıldığı bir çarşıdır. Her bir kapısında bir eşyanın mezadı yapılıyordu. Bu manada bedestendeki her bölüm kendi alanında uzmanlaşmışt1. Mücevherciler bölümündeki mezatta her gün türlü türlü değerli taşlardan yapılmış eşyalar alınıp satılmaktaydı. Kuyumcu dükkânlarının çoğu burada sıralanıyordu. Dükkânlarda satılan eşyaların fiyatlarına örnek vermek gerekirse, XVIII. yüzyılın ilk yarısında bir çift küpe 580 kuruş, bir kürk 600 kuruş ve üzeri, bir fincan 70 kuruş, bir Kurân-1 Kerîm 250 kuruşa alıcı buluyordu. ${ }^{87}$

Bunun dışında Camii meydanları çevresinde dükkânların yer aldığı çarşılar vardır. Eminönü’ndeki Valide Sultan Camii’nin ön tarafında Eminönü İskelesi bulunmaktadır. Buraya her türlü deniz ürünleri getirilmektedir. Ayrıca türlü çeşit meyve, sebze ve çiçek burada satılmaktadır ${ }^{88}$. Kentin diğer önemli ve büyük çarşısı Mısır Çarşısı olup Eminönü semtinde bulunmaktadır. Burası her türlü ilaç ve baharat, keten ve şekerin satıldığı alan olarak uzmanlaşmıştır. ${ }^{89}$

Bayezıt Camii civarı her türlü sanat ve meslek erbabının bulunduğu bir yerdir. Kaşıkçı, bıçakçı, semerci, bakırcı, bardak ve küp satanlar çoğunlukla buradaydı. ${ }^{90}$ Yine paraların basıldığı darphane ile vezneciler, hurdacılar, keresteciler de Bayezıt Camii etrafında yer almaktadir. ${ }^{91}$

Fatih Camii'nin avlusunun dört bir yanı çarşı pazar olup buralarda her türlü eşya açıkta satılırdı. ${ }^{92}$ Fatih Camii Meydanı civarı oldukça kalabalıktır, buralar alışverişe gelen insanlarla dolup taşmaktadır. Burada iktisadî ve dinî faaliyetlerin yanı sıra ahlaka mugayir davranışlarında sergilendiği anlaşılmaktadır. Fatih Camii Meydanı civarındaki çarşı alanları, fuhuş gibi gayri ahlaki davranışları sergileyen kadın ve erkeklerin uğrak yerleri arasındaydı. Genel olarak toplum nazarında hoş karşılanmayan bu hallerde bulunan kimselere vatandaş müdahale edemezdi. Bu kimselere sadece asayiş görevlileri müdahale edebiliyordu. Çarşı halkı ise bunlara sadece bakmakla yetinirdi. ${ }^{93}$

Çarşı ve pazarlarda dolaşıp alışveriş yapan kadınların sayısı erkeklerden daha fazladır. Yerli bir gezgin olan Resmî Kayserî, özellikle Cuma günleri süslenip ziynetler

86 Resmî Kayseri, Seyahat-nâme, s.156a.

Resmî Kayseri, Seyahat-nâme, s.156b.

8 Resmî Kayseri, Seyahat-nâme, s.155b.

89 Karakuyu-Balık, "İstanbul'un Tarihsel Topoğrafyası...”, s.43; Resmî Kayseri, Seyahat-nâme, s.155b.

90 Resmî Kayseri, Seyahat-nâme, ss. 150b-151a.

1 Resmî Kayseri, Seyahat-nâme, s.153b.

92 Resmî Kayseri, Seyahat-nâme, s.150a.

93 Resmî Kayseri, Seyahat-nâme, s.150a. 
takınan bütün kadınlar buralara akın ettiklerinden bahsetmektedir. Müellif kadınların bahsi geçen şekilde oldukça gösterişli giyinmelerini dinî yönden -erkekleri olumsuz etkilemeleri açısından- tehlike olarak algılamaktadır. ${ }^{94}$

Dükkân ve ticarethanelerin dışında günlük ihtiyaçların karşılandığı başka yerler vardı. Bunlar Pazar olarak anılırdı. Bu pazarlardan Bit Pazarı'nda kullanılmış elbise, At Pazarı'nda beygir ve katır, Tavuk Pazarı'nda tavuk ve emsali hayvanlar satılırdı. Kervansaray gibi pek çok odadan oluşan Esir Pazarı'nda Afrika, Gürcü, Abaza ve diğer milletlerden getirilen erkek ve kadın köle satışı yapılırdı. ${ }^{95}$

İstanbul'u tam da III. Ahmed Devri sıralarında birkaç kez ziyarete gelen seyyah kentin çarşı pazarlarının çokluğu ve çeşitliliği için şunları söylüyordu:

\footnotetext{
"Nefs-i İstanbul'un hangi yerine gitsen çarşı pazardır. Bir mahalle yoktur ki orada çarşı mükemmel olmasın. Her ne şey var ise orda vardır. Dünyada en ucuz ve pahalı ara, kızlık ara, iyi-kötü ara her şey buralardadır. Yani filan yerde filan şey ucuzdur diyerek alıp İstanbul'da satmak istersen zarar edersin. Çarşıların birinde bir eşyaya rast gelirsin ki yarı pahasına satılır işte hâli böyledir ${ }^{96 "}$.
}

Her türlü mal ve eşya satılan diğer pazar yerleri ise haftanın yedi gününde belirli mahallerde kuruluyordu. Pazar günü Samatya civarında Avret Pazarı, pazartesi günü Mısır Çarşısı yanında kurulan pazar oldukça rağbet görüyordu. Salı günü Topkapı önünde uzanan yolun iki tarafında, Çarşamba günü Fatih Camii arkasındaki mahalde bir pazar kuruluyordu. Karagümrük'te Edirnekapı ile Fatih Cami arasındaki alanda Perşembe günü, Kocamustafa Paşa'da Cuma günü, Eski Ali Paşa'da ise Cumartesi günü pazar kuruluyordu. Dolayısıyla sokak manzaraları oldukça renkliydi. Bayezıt, Büyük Çarşı, Eminönü, Galata ve Kasımpaşa gibi hareketli, kalabalık, gürültülü semtler gün boyunca kentsel faaliyetlerin yoğunlaştığı yerlerdir. Buralarda sadece tüccarlar, dükkân sahipleri, zanaatkârlar gibi geçimlerini buradan sağlayan insanlar değil aynı zamanda buraya alış verişe ve gezmeye gelenler ile buralara yük getiren kervanlarla da vardı. Bu nedenle de bu mahalleler diğerlerine göre daha kalabalık ve canlıydı.

\footnotetext{
94 "Be-gâyet metin yiğid ister ki anları göre sabr eyleye. Hak subhanehu ve ta’âlâ cem'î din karındaşlarumuzı şer'lerinden hıfz eyleye...” Resmî Kayseri, Seyahat-nâme, s.150a.

95 İncicyan, XVIII. Astrda İstanbul, s.35.

96 Resmî Kayseri, Seyahat-nâme, s.158a.
} 
Çarşı ve pazarlarda aşırı derecede kalabalık olup buralarda dolaşanlar, alışveriş yapanlar çoğunlukla kadınlardır. Buralar kadın erkek herkese hitap ettiğinden çekim merkezleri olarak oldukça kalabalıktır. $^{97}$

Sonuç olarak asıl İstanbul olarak adlandırdığımız tarihi yarımada içinde yerleşim alanları camilerin etrafında büyüyerek şekillenmiştir. Müslüman halkın çoğunluğunu oluşturduğu mahallelerde gayrimüslimler çoğunlukla kendilerine tahsis edilmiş alanlarda bazen de Müslüman ahali ile birlikte yaşamaktaydı. Önceki devirlerde olduğu gibi III. Ahmed devri İstanbul'unda mahalle içinde ekonomik ve sosyal hayatta belirgin bir statü farkı olmadığını söylenebilir. Bu tarihlerde İstanbul dünyanın büyük şehirlerinden biri olma özelliğini korumuştur. Kentin nüfus yoğunluğu artmaya devam ettiği için iaşesinin sağlanması önemli sorunlardan biri olmuştur. Halkın iaşesi kısmen şehir ve çevresindeki üreticilerden büyük ölçüde ise dişardan tedarik ediliyordu. Özellikle sebze ve meyve gibi gıdalar dayanıksız oldukları için sebzeler kentteki bahçe ve bostanlardan elde ediliyordu. Bunlar göz önünde bulundurulmuş olmalı ki İstanbul bostanları kalabalık nüfuslu kentin ihtiyaçlarını karşılayacak şekilde düzenlenmiştir. Bahsi geçen bahçeler dışında halkın vakit geçirmesi ve eğlenmesi amacıyla suriçi ve dışında çok sayıda mesire alanları, bahçeler ve çayırlar vardı. Hümayunâbâd, Hüsrevâbâd, Sa'dâbâd gibi saray ve çeşmeler yapıldı. İstanbul'un siluetini oluşturan önemli yapılardan biri de çarşı pazarlardır. III. Ahmet devrinde kentin dört bir köşesinde her şeyin mevcut olduğu uzmanlaşmış satış yerleri vardır. Çarşılardan başka haftanın belirli günlerinde kurulan pazarlar da halkın rağbet ettiği mekânlar arasındadır. Oldukça kalabalık olan bu yerlerde ihtiyaca yönelik her türlü gıda, giyecek maddesi ve benzeri mallar bulunduğundan olsa gerek buralar alışverişe gelen insanlarla dolup taşmaktadır. İktisadî hayatın yürütüldü çarşı pazarlar aynı zamanda gündelik ve sosyal hayatın da yürütüldüğü mekânlar olarak göze çarpmaktadır.

97 Resmî Kayseri, Seyahat-nâme, s.157b. 


\section{KAYNAKÇA}

1. Arşiv Belgeleri

1.1. İstanbul Mahkemesi Şer'iye Sicili

Şer'iye Sicil No

24

Ait Olduğu Tarih

1.2 İstanbul Bab Sicilleri

Şer'iye Sicil No

88

90

:1138-1151/1726-1738

91

Ait Olduğu Tarih

: 1119-1120/ 1707-1708

: 1120/ 1708-1709

: 1120-1121/ 1707-1710

93

: 1121-1122/ 1710-1711

99

: 1124/ 1712-1713

100

: 1124-1125/1712-1713

105

: 1126/ 1714-1715

106

: 1126/ 1714-1715

107

: 1126-1127/ 1714-1715

108

: $1127 / 1715$

109

: $1127 / 1715$

114

: 1128-1129/ 1715-1717

118

: 1130/ 1717-1718

119

: 1130/ 1717-1718

121

: 1130-1131/ 1717-1719

$146 \quad 123$

: 1131-1132/1718-1720

124

: 1132-1133/ 1719-1721

125

: 1133/1720-1721

127

: 1133-1134/ 1720-1722

128

129

: 1134-1135/ 1721-1723

: 1135/1722-1723

131

: 1136/1723-1724

133

: 1136-1137/ 1723-1725

134

: 1137/ 1724-1725

135

: 1137/ 1724-1725

139

: 1138-1139/1725-1727

140

: 1138-1139/1725-1727

142

143

144

145

150

152

: 1139/1725-1727

: 1139-1140/ 1725-1728

: 1140/ 1727-1728

: 1140-1141/ 1727-1729

: 1143/1730-1731

: 1144/ 1731-1732

153

: 1144/ 1731-1732

154

: 1144/ 1731-1732

156

: 1145/ 1732-1733

157

: 1145-1146/ 1732-1734

158

: 1146-1147/ 1733-1735

159

: 1146-1147/ 1733-1735 
İstanbul Balat Sicilleri

Şer'iye Sicil No Ait Olduğu Tarih

23

: 1141-1143/ 1728-1731

24

: 1143-1144/ 1730-1732

Resmî Kayseri, Seyahat-nâme, Milli Kütüphane Yazmalar, A.4277/2.

\section{Tetkik Eserler}

Altınöz, İsmail; Osmanlı Toplumunda Çingeneler, Ankara; TTK, 2013.

Aktepe, Münir; “XVII. Asra Ait İstanbul Kazası Avarız Defteri”, İstanbul Enstitüsü Dergisi, III, İstanbul 1957, s.114.

; “XVIII. Asrın ilk Yarısında İstanbul Nüfusu Meselesine Dair Bazı Vesikalar", IÜEFTD, C.IX, S.13, 1958, s.1-35.

Altınay, Ahmet Refik; Eski İstanbul, Sami Önal (haz.), İstanbul; İletişim Yayınları, 1998.

Ayvazoğlu, Beşir; “Ağaçlar ve Bahçeler”, Şehir ve Kültür İstanbul, Ahmet Emre Bilgili (ed.), İstanbul; Profil yay, 2011.

; “İstanbul Kültürü ve Estetiği”, Şehir ve Kültür İstanbul, Ahmet Emre Bilgili (ed.), İstanbul; Profil yay, 2011.

Ayverdi, E. Hakkı; Fatih Devri Sonlarında Istanbul Mahalleleri, Şehrin İskânı ve Nüfusu, Ankara: Vakıflar Umum Müdürlüğü Yay., 1958.

Beydilli, Kemal; Osmanlı'da İmamlar ve Bir Imamın Günlüğü, İzmir; Yitik Hazine Yay., 2013.

Bilgin, Arif; “Osmanlı Dönemi İstanbul Bostanları (Bir Giriş Denemesi1, Yemek ve Kültür, İlkbahar 2010, S. 20, ss.86-97.

Çabuk,Suat-Kemal Demir; “Osmanlı Kentlerinde Mahallelerin Mekânsallaştırılabilmesi İçin Bir Yöntem Denemesi: Kayseri Örneği”, Tarih Kültür ve Sanat Araştırmaları Dergisi, Vol.1, No.3, September 2012.

Cevdet Paşa, Tezâkir, II. Seri, TTK Basımevi, Ankara 1960. 
Emiroğlu, Öztürk; "Polonyalı İki Gezginin Kaleminden XIX. Yüzyıl İstanbul'u”, 7. Uluslararası Türk Kültürü Kongresi, Bildiriler: II, Şebnem Ercebeci Çınar (yay. haz.), s.103.

Erken, İlkay; Isşkodra Vilayetinin İdari ve Sosyal Yapısı, Basılmamış Yüksek Lisans Tezi, Samsun 2014.

Evliya Çelebi Seyahatnâmesi 1. Kitap, Topkapı Sarayı Kütüphanesi 304 Numaralı Yazmanın Transkiripsiyon- Dizin, R. Dankoff- S.A. Kahraman- Y. Dağlı (haz.), İstanbul; YKY Yay, 2006.

Işın, Ekrem İstanbul'da Gündelik Hayat, İstanbul; YKY, 2006.

İncicyan, P. Ğ. ; 18. Asırda İstanbul, Hrand D. Andreasyan (çev.), İstanbul; İstanbul Enstitüsü Yay., 1976.

Mantran, Robert; Istanbul Tarihi, İstanbul; İletişim Yay, 2002.

; XVI. ve XVII. Yüzyılda İstanbul'da Gündelik Hayat, Mehmet Ali Kılıçbay, (Fransızca aslından çev.), İstanbul; Eren yay, 1991. ; XVII. Yüzyllın İkinci Yarısında İstanbul (Kurumsal, İktisadi, Toplumsal Tarih Denemesi), C.I, İstanbul; TTK, 1990.

Nedim; Divanı; Abdülbaki Gölpınarlı (haz.), İstanbul; İnkılâp ve Aka Kitabevleri, 1972.

Ortaylı, İlber; “İstanbul'da Tarihi Yaşamak”, Şehir ve Kültür İstanbul, İstanbul; Profil yay, 2011.

Râşid Mehmed Efendi-Çelebizâde İsmaîl Âsım Efendi; Târih-i Râşid ve Zeyli, Andülkadir Özcan-Y. Uğur-B. Çakır-A.Z. İzgöer (haz.), C.II, İstanbul; Klasik Yay, 2013. 